\title{
Flavonoids as Epigenetic Modulators for Prostate Cancer Prevention
}

\author{
Simona Izzo ${ }^{1}$, Valeria Naponelli ${ }^{1,2,3, *(D)}$ and Saverio Bettuzzi 1,2,3 \\ 1 Department of Medicine and Surgery, University of Parma, Via Volturno 39, 43125 Parma, Italy; \\ simona.izzo@unipr.it (S.I.); saverio.bettuzzi@unipr.it (S.B.) \\ 2 National Institute of Biostructure and Biosystems (INBB), Viale Medaglie d'Oro 305, 00136 Rome, Italy \\ 3 Centre for Molecular and Translational Oncology (COMT), University of Parma, Parco Area delle Scienze \\ 11/a, 43124 Parma, Italy \\ * Correspondence: valeria.naponelli@unipr.it; Tel.: +39-0521033817
}

Received: 17 March 2020; Accepted: 3 April 2020; Published: 6 April 2020

check for updates

\begin{abstract}
Prostate cancer (PCa) is a multifactorial disease with an unclear etiology. Due to its high prevalence, long latency, and slow progression, $\mathrm{PCa}$ is an ideal target for chemoprevention strategies. Many research studies have highlighted the positive effects of natural flavonoids on chronic diseases, including PCa. Different classes of dietary flavonoids exhibit anti-oxidative, anti-inflammatory, anti-mutagenic, anti-aging, cardioprotective, anti-viral/bacterial and anti-carcinogenic properties. We overviewed the most recent evidence of the antitumoral effects exerted by dietary flavonoids, with a special focus on their epigenetic action in PCa. Epigenetic alterations have been identified as key initiating events in several kinds of cancer. Many dietary flavonoids have been found to reverse DNA aberrations that promote neoplastic transformation, particularly for PCa. The epigenetic targets of the actions of flavonoids include oncogenes and tumor suppressor genes, indirectly controlled through the regulation of epigenetic enzymes such as DNA methyltransferase (DNMT), histone acetyltransferase (HAT), and histone deacetylase (HDAC). In addition, flavonoids were found capable of restoring miRNA and lncRNA expression that is altered during diseases. The optimization of the use of flavonoids as natural epigenetic modulators for chemoprevention and as a possible treatment of PCa and other kinds of cancers could represent a promising and valid strategy to inhibit carcinogenesis and fight cancer.
\end{abstract}

Keywords: prostate cancer; flavonoids; epigenetic regulation; miRNAs; green tea catechins; natural compounds; IncRNAs; apoptosis; cell cycle arrest; chemoprevention

\section{Introduction}

Prostate cancer (PCa) is a multifactorial disease. Abnormal growth of cells may become invasive, leading to the spread and metastasizing to different tissues in the body. Worldwide, PCa is the second most frequently diagnosed cancer and the fifth leading cause of cancer death [1]. Due to the increase in testing, PCa diagnosis has grown exponentially in recent decades. Nowadays, this disease is considered the most common, life-threatening tumor affecting the European male population [1]. However, most prostate cancers are indolent: they rarely progress towards clinical significance. However, it is difficult to discriminate between clinically-significant and clinically-insignificant PCa [2] When a man receives a PCa diagnosis, the most likely treatment options are surgical removal of the gland, chemotherapy, and/or radiotherapy. These are especially effective in the early stage of the disease but become useless for locally advanced or metastasized PCa. In fact, some patients eventually develop an aggressive form that resists treatment (castration-resistant prostate cancer, CRPC). When this happens, after an initial response, PCa cells no longer respond to androgen deprivation therapy [3-5]. 
The etiology of PCa has not be fully clarified; however, it is known that, in addition to genetic and biological factors, such as ethnicity, predisposition, and geographic location, environmental factors like diet and lifestyle can strongly influence the risk of PCa [6-12].

Cancer chemoprevention, whose definition is the use of non-toxic natural or synthetic molecules to prevent, inhibit, or reverse the onset and progression of cancer, is currently one of the most studied and promising fields of research $[13,14]$. Due to its high prevalence, long latency, and slow progression, $\mathrm{PCa}$ is an ideal target for chemoprevention strategies. Many research studies have highlighted the positive effects of natural compounds, such as vitamins, phenols, flavonoids, and mineral substances on chronic diseases [15-18]. In particular, polyphenols are one of the most studied class of phytochemicals because of their anti-inflammatory, antiviral, anti-allergic, antioxidant, and antitumoral effects [19-21]. The most common classes of polyphenols are flavonoids and phenolic acids, representing approximately $60 \%$ and $30 \%$ of all natural polyphenols, respectively $[22,23]$.

\section{Flavonoids}

\subsection{Structure and Metabolism}

Flavonoids are a class of secondary plant metabolites generally used by vegetables for their growth and defense against microbes [24].

Flavonoids cannot be synthesized by humans and animals but are important components in the human diet. They are associated with many healthy effects due to their anti-oxidative, anti-inflammatory, anti-mutagenic, anti-aging, cardioprotective, anti-viral/bacterial, and anti-carcinogenic properties, together with their capacity to modulate enzyme function [24].

Their structure is based upon two benzene rings ( $\mathrm{A}$ and $\mathrm{B}$ ring) that are linked via a heterocyclic pyran ring (C ring) containing oxygen (Figure 1) [25].

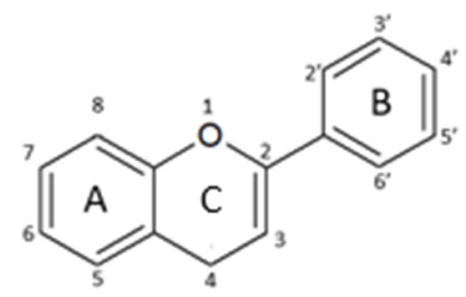

Figure 1. General structure of a flavonoid.

Based on their structural differences, flavonoids can be divided into (Table 1):

- $\quad$ Flavones: have a double bond between $\mathrm{C} 2 \mathrm{C} 3$ and a C4-oxo function;

- Flavonols: are flavone analogues with a 3-hydroxylic group;

- Flavanones: are flavone analogues but with a C2-C3 single bond;

- Isoflavonoids: have the $\mathrm{B}$ ring attached at $\mathrm{C} 3$, rather than $\mathrm{C} 2$ position of the $\mathrm{C}$ ring;

- $\quad$ Flavanols or catechins: are the 3-hydroxy derivatives of flavanones, they have the hydroxyl group always bound to position 3 of the $\mathrm{C}$ ring;

- $\quad$ Anthocyanins: have a basic chemical structure with a flavylium cation, which binds the hydroxyl and/or methoxyl group(s) in $R_{1}, R_{2}$, and $R_{3}$ position. 
Table 1. Structure of the main flavonoid compounds. Based on their structural differences, flavonoids can be divided into flavones, flavonols, flavanones, isoflavonoids, flavanols, and anthocyanins. Flavonoids whose epigenetic action is detailed in the text are in bold.

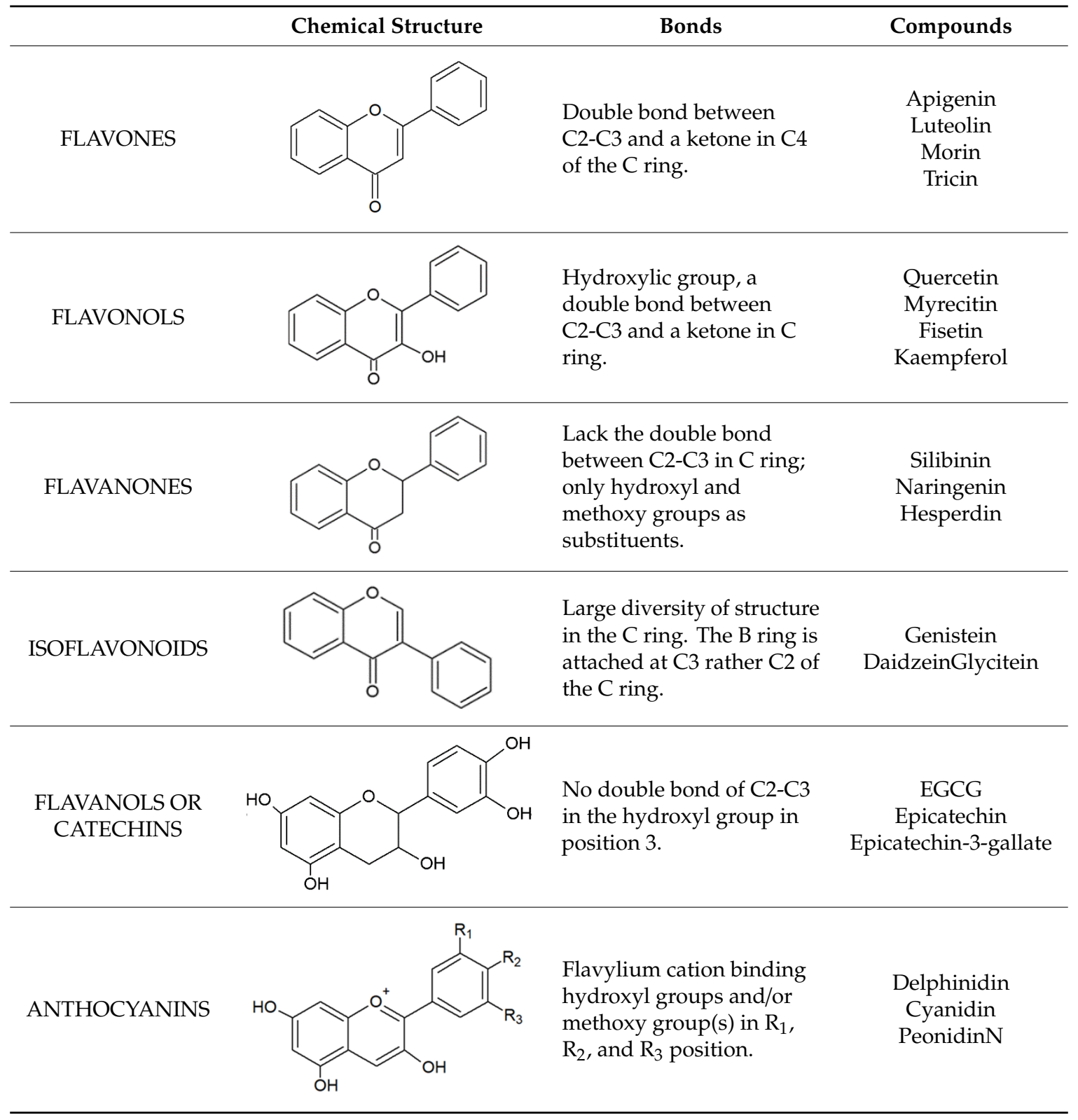

Generally, the color and taste of food are conferred by flavonoids, which also play a role in the prevention of fat oxidation and the protection of vitamins and enzymes [25]. The scientific interest in these compounds has increased as of late, mainly due to their potential to promote health and reduce the risk of disease.

Flavonoids are generally found in plants as free aglycones (the basic form of flavonoids), glycosides, and methylated derivatives.

The physical and chemical properties of dietary flavonoids affect their ability to be absorbed by the intestine; while the small intestine can easily absorb flavonoid aglycones, the flavonoid glycosides, which are bound to sugars and represent the majority of these polyphenols, must be converted to the a glycan form by $\beta$-glucosidases before being absorbed $[25,26]$. No free flavonoids are present in plasma or urine since the absorbed flavonoids are immediately conjugated in the liver. 
Many studies performed both in vitro and in vivo demonstrated the anti-tumoral effects of flavonoids on different types of cancer [27-29]. Epidemiological studies have shown an association between plant-derived flavonoids consumption and cancer risk reduction [29-31].

Regarding more specifically PCa, in vivo pre-clinical studies have evidenced the chemopreventive effect of natural compounds in PCa xenograft mouse models and in transgenic mouse models. Although the association between polyphenols intake and tumorigenesis of PCa needs to be confirmed by large-scale epidemiological data [32], since results are sometimes inconsistent and conflicting, there is a general agreement that consumption of flavonoids in the diet significantly reduces PCa risk [33-37].

The bioavailability of the different flavonoids differs between individuals. For this reason, there is a lack of correlation between the dose administered and the concentration measured in the human body. Moreover, metabolites, rather than pure polyphenol, often show the greatest biological activity [38,39]. When studying pharmacokinetics, each step, as well as all the enzymes implied in its absorption, modification, and transport, should be taken into account for a better understanding of the beneficial effects of flavonoids [40]. Flavonoids are generally well tolerated by prostate cells [41]. However, the potential toxic effects of excessive flavonoid intake are often ignored; it is likely that they act as mutagens, inhibitors of key regulatory enzymes, or as pro-oxidant molecules. Therefore, it is important to not exceed the intake levels that have been demonstrated useful in vivo [42]. No important side effects have been demonstrated when given up to $1 \mathrm{~g} /$ die in humans [43]. Many different kinds of polyphenols have been studied in the attempt to kill PCa cells [44-51].

\subsection{Biological Activity of Flavonoids}

Flavonoids, thanks to their anti-oxidant, anti-cancer, anti-microbic, anti-viral and anti-aging activities, cause a variety of biological effects on different types of cells.

\subsubsection{Anti-Oxidant and Pro-Oxidant Activity}

Reactive oxygen species (ROS) play an important role in many human diseases, such as cancer or neurodegenerative diseases. In fact, ROS can combine with and oxidize many biomolecules, causing damage to cells, tissues, and organs [52,53]. Hydroxyl $\mathrm{OH} \bullet$, superoxide $\mathrm{O}_{2} \bullet-$, nitric oxide $\mathrm{NO} \bullet$,

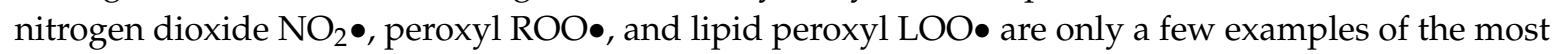
common reactive species constantly formed during cell metabolism. They are believed to contribute to cellular aging, mutagenesis, and carcinogenesis [54-56].

The anti-oxidant effects of flavonoids are explained by the number and arrangement of the hydroxyl groups around the nuclear structure [25].

Anti-oxidant activity is exerted through two major modalities: flavonoids can act as radical scavengers that either prevent the cellular damage produced by ROS or prevent the generation of ROS in the first place.

Flavonoid action is mediated by inhibition of the enzymes involved in ROS generation (such as glutathione $\mathrm{S}$ transferase, mitochondrial succinoxidase, NADH oxidase), or by an increase of anti-oxidant and detoxifying enzymes levels (such as glutathione peroxidase, glutathione reductase, and catalase) $[25,57]$. Reduction of ROS mediated by flavonoids is demonstrated in different PCa cell lines $[58,59]$.

Moreover, flavonoids exhibit a pro-oxidant action, which is mainly ascribable to their ability to strongly chelate metal ions, such as $\mathrm{Cu}$ and Fe. The generation of a radical or a redox complex with a transition metal ion can cause damage in the DNA chain and mutations in gene expression [60]. For example, quercetin has been described as acting as a pro-oxidant or an anti-oxidant molecule, depending on the PCa cell line; in DU-145 cells, quercetin administration led to a ROS increase, while in LNCaP and PC3 cells, a ROS quenching activity was measured [61]. 


\subsubsection{Anti-Proliferative and Cytotoxic Effect}

Multiple signaling pathways that play an important role in cancer development are the targets of many flavonoid compounds. Many of the protein effectors, which are found in multiple pathways, are improperly activated or abnormally expressed in several cancers. One of the most studied pathways involves Ras/Raf/Mitogen-activated protein kinase kinase (MEK)/Mitogen-activated protein kinase (MAPK) signaling. The binding of a ligand, or a growth factor, to a tyrosine kinase (RTK) receptor activates Ras, which stimulates the activation of several protein kinases such as Raf. Raf phosphorylates MEK1/2 which activates MAPKs or MAP kinase kinase (MKK) signaling. The downstream effectors of the MAPK include extracellular signal-regulated protein kinases (ERKs) and 90-kDa ribosomal S6 kinases (RSKs), while MKK triggers c-Jun N-terminal kinases (JNKs). In cancer cells, including those of the prostate, many of these kinases are constitutively activated, thus causing cell transformation and tumor growth [62].

One of the main targets of this pathway is activator protein 1 (AP-1), which is involved in cell-cycle progression. The main targets of AP-1 belong to two subfamilies of transcription factors, Jun and Fos. Jun and Fos activate other transcription factors, such as activating transcription factor 2 (ATF 2), cAMP response element-binding, nuclear factor of activated T-cells, or Sma- and Mad-related protein (SMAD) protein. The result of activation of this pathway is the increase of proliferation, angiogenesis, metastasis, and survival. Flavonoid compounds, such as delphinidin, quercetin, and myricetin, have been shown to interact with MEK, inhibiting its activity in an ATP noncompetitive fashion [63-65].

Flavonoids, such as luteolin or myricetin, are also able to exert their antitumor effect through direct binding to Fyn or Src proteins, non-receptor tyrosine kinases that can activate the Ras/Raf/MEK/MAPK pathways in the ATP-binding site [66,67].

Phosphoinositide-3-kinase (PI3K)/phosphatase and tensin homolog (PTEN)/Akt/ mammalian target of rapamycin (mTOR) signaling represents another pathway that is dysregulated in different types of cancer and can be hit by flavonoid compounds. PI3K, Akt, and mTOR are oncogenic proteins, while PTEN is a tumor suppressor. The oncoprotein Akt can be activated by mutations in PI3K, by loss of expression or activity of PTEN, or in response to induction by growth factors. mTOR, an effector of Akt signaling, controls nuclear factor kappa-light-chain-enhancer of activated B cells (NF-kB) transcriptional activity that modulates cell proliferation and apoptosis [68]. Flavonoids act by means of the inhibition of phosphorylation and activity through their binding to Akt or PI3K, or they can act by reducing UVB-induced phosphorylation of Akt. The effects of the inhibition, in general competitive with ATP, of PI3K or Akt by flavonoids, include suppression of Cyclooxygenase-2 (COX-2) expression, and a decrease in cell migration and metastasis-inducing proteins, such as metalloproteinase (MMP)-9, MMP-13, and vascular endothelial growth factor (VEGF) [68-70]. These pathways are fully and clearly reviewed in by Bode and Dong [62], and also described in PCa cells [61,71-73].

Androgens and androgen receptors are required for the development of the male urogenital system and are involved in prostate cells proliferation. In fact, androgen deprivation is the first therapeutic approach for $\mathrm{PCa}$, generally leading to a first positive response of patients, until they later become "androgen refractory". Flavonoids exert anti-androgenic effects through multiple mechanisms, such as inhibition of transactivators of androgen receptors, inhibition of the androgen receptor activity, or even by direct competition, mainly due to the structural similarity between these natural compounds and natural hormones [57].

\subsubsection{Cell Cycle Arrest and Apoptosis Induction}

Flavonoids have been shown to decrease cell viability of cancer cells through induction of cell cycle arrest and activation of apoptosis. Cyclins and cyclin-dependent kinases (CDKs) form the main regulator complexes of the progression through the four phases of the cell cycle. In normal cells, the cell cycle is tightly regulated. In contrast, the cell cycle control is usually lost in tumor cells. Most flavonoid compounds induce cell cycle arrest through the alteration of cyclin levels: apigenin was found to reduce the level of cyclin D1, causing cell cycle arrest in the G0/G1 phase for PC3 and LNCaP PCa 
cell lines, and in G2/M phase for DU-145 cell line [74,75]. Polyphenon E, a standardized catechin extract, caused a G0/G1 cell cycle arrest in PNT1 cell line, and a G2/M arrest in PC3 cells [76]. Quercetin administration has been associated with a reduction in the levels of cyclin E, cyclin D, and CDK2 in PC3 cells, with a consequent arrest of cell cycle in G0/G1 phase [57,77].

Apoptosis is a form of programmed cell death caused by a set of precise cellular events that change the morphology and the functions of the cell. Apoptosis is important for tissue integrity and development; it can be initiated by the activation of cell death receptors via caspases- 8 and -10 activation (extrinsic pathway) or by a cell stress sensed and triggered by activated mitochondria via activation of executioner caspases (intrinsic pathway). In normal cells, apoptosis is fundamental for the maintenance of tissue homeostasis and for the destruction of abnormal cells, such as tumor cells, which, conversely, have developed mechanisms to circumvent this process, such as the reduction of caspases expression or the loss of activity of cell death receptors.

Flavonoids have been shown to induce apoptotic death in many cancer cell lines [78,79].

In PCa cells, for example, apigenin has been shown to induce death receptor 5 and pro-apoptotic factors like tumor necrosis factor (TNF)-related apoptosis-inducing ligand (TRAIL), or higher levels of caspase- 3 and -8 in cancer stem cells $[57,73,80]$. Fisetin decreased the activity of NF-kB in DU145 and PC 3 cells and caused the activation of caspase- 3 and -8 concomitantly with the disruption of the mitochondrial membrane [81]. Quercetin, in combination with EGCG, induced p53-mediated apoptosis in LNCaP and PC3 cells [82]. Polyphenon E induced endoplasmic reticulum stress, leading to death by anoikis in PNT1a and by necroptosis in PC3 cells [76].

\section{Epigenetic Modifications Induced by Flavonoids}

\subsection{Epigenetics in Prostate Cancer}

The term "epigenetic modifications" describes a stably hereditable change in DNA or associated proteins that affect and alter gene expression without modifying the DNA sequence [83]. These changes alter the structure of the chromatin and have an impact on the accessibility of promoters to the transcriptional machinery [84]. Possible alteration of gene expression may cause aberrant induction, or inhibition, of the main intracellular enzymatic and molecular cascades, leading to many diseases, including cancer. During the transformation of prostate cells into cancer cells, epigenetic alteration was frequently observed, and in most cases, it was found to precede any genetic mutations [85]. The main epigenetic modifications include DNA methylation, histone modification, nucleosome positioning, and expression of non-coding RNAs [83].

\subsubsection{DNA Methylation}

DNA methylation consists of the covalent addition of a $-\mathrm{CH}_{3}$ group to the cytosine ring of the CpG dinucleotide. This dinucleotide is generally present at high density in specific, short regions of the human DNA (CpG islands). When these CpG islands are unmethylated, the chromatin is accessible, and the transcriptional machinery can easily attach the DNA and proceed towards gene expression. In all normal tissues, promoter regions are generally present in CpG islands in non-methylated form, while in PCa cells the promoters are commonly hypermethylated; consequently, genes are repressed. In cancer cells, the CpG islands present in suppressor genes are often hypermethylated, resulting in gene inactivation. This would sustain cells growth and spreading of cancer cells [86]. In PCa, methylation of hormone receptor genes, such as androgen, estrogen, or progesterone receptors, is a late stage event of carcinogenesis [87]. Genes involved in the regulation of important cellular processes, such as DNA repair, migration, cell cycle regulation, and apoptosis have been shown to have altered behavior due to aberrant promoter, or gene methylation, in PCa cells [88-93].

DNA methyltransferases (DNMTs) are the enzymes responsible for DNA methylation. They include three isoenzymes: DNMT1, which is involved in maintaining the post-replicative 
methylation pattern of DNA, and DNMT3a and DNMT3b, which are recruited for de novo DNA methylation [86,94]. Late stage PCa tissues have methylated androgen receptor promoters [86].

Another epigenetic change commonly found in human cancers is the loss of DNA methylation that is frequently associated with increased transcription. In PCa, DNA hypomethylation is generally observed in the late stage of cancer progression, when lymph nodes have been invaded [86,95].

\subsubsection{Histone Modifications}

Histones are positively charged proteins with the role of packing DNA in ordered structures called nucleosomes. Nucleosomes are the basic repeating structural units of chromatin. Histone covalent modifications, such as acetylation, phosphorylation, and methylation, determine chromatin structure changes that influence gene expression. If the chromatin is open (euchromatin), transcription is activated, whereas, when the chromatin is closed (heterochromatin), transcription is inhibited.

Histone acetylation is the covalent addition of an acetyl group to the lysine residues present in the histone tail by the histone acetyltransferases (HATs); this precise modification allows the expression of genes. Therefore, HATs are considered transcriptional co-activators. Conversely, histone deacetylases (HDACs) are a family of enzymes acting as co-repressors of transcription, as they de-acetylate the histone tails of the nucleosome, thus favoring the gene repression [96].

Generally, an increased activity of HDACs is correlated with increased prostate-specific antigen (PSA) serum levels and tumor cell invasiveness in PCa cells.

Another epigenetic modification is catalyzed by histone methyltransferases (HMTs), enzymes able to transfer methyl groups from S-adenosyl methionine (SAM) to a lysine or an arginine residue of the histone tail, while the same groups are removed by histone demethylases (HDMs). The activation or repression of genes transcription depends on the position and the level of methylation of the histones. Prostate cancer-specific transcription profiles are often related to the regulation of histone methylation [97,98]. Histone phosphorylation is mediated by several kinases (stress-activated protein kinase, kinase Aurora B, etc.), and is generally related to the cell cycle. The phosphorylation of serine, located four residues from the $\mathrm{C}$ terminus of H2A histone family member $\mathrm{X}$ (H2AX), which is a marker of DNA double strand break, an alteration leading to genomic instability and, eventually, to cancer [99]. Phosphorylation of histone H2AX, which is catalyzed by kinases belonging to the family of phosphatidylinositol 3-kinase-related protein kinases, determines the chromatin relaxation. In PCa, the presence of phosphorylated histone H2AX is linked to prostate cell transformation [100].

\subsection{3. miRNA}

MicroRNAs (miRNAs) are small non-coding RNAs composed of 18-25 nucleotides that specifically regulate gene expression. They exert oncogenic (oncomirs) or tumor suppressor effects, often interacting with the $3^{\prime}$ region and, rarely, with the $5^{\prime}$ untranslated region of the mRNA target. In this way, miRNA affect the stability of the transcripts and/or stop gene translation. One miRNA can interact and modulate the expression of several genes; in consideration of this fact, few miRNAs are enough to cause an amplified dysregulation of a broad range of important cellular processes. Moreover, several miRNAs can target the expression of a specific mRNA [101]. The alteration of miRNA expression can be due to genetic alterations, promoter hypermethylation, or epigenetic modifications and can promote and coordinate cancer onset and progression.

Several studies describe an alteration of the miRNA profile in PCa whereby miRNAs are used as biomarkers to distinguish indolent and aggressive cancers. The most common oncomirs found in PCa are miR-21, miR-32, miR-221, miR-222, miR-181, miR-18a, and miR-429. miR-21 and miR-32 are two androgen-regulated oncogenic miRNAs that target tumor suppressors, thus promoting cell proliferation. In particular, miR-21 targets reversion inducing cysteine rich protein with Kazal motifs (RECK) gene and promotes cell invasion and metastasis through the control of matrix metalloproteinase 9 (MMP-9) or interacts and downregulates phosphatase and tensin homolog (PTEN) and programmed cell death (PDCD4), favoring apoptosis inhibition and tumor progression. miR-32 targets B-cell 
translocation gene 2 (BTG-2) and phosphoinositide-3-kinase interacting protein 1 (PI3KIP1) regulating cell proliferation, survival, and cell invasiveness. miR-221, miR-222, and miR-429 modulate the expression of cell cycle regulators. miR-18a acts as an oncomir: it targets the serine/threonine kinase 4 (STK4) 3' untranslated region, inducing its downregulation and promoting tumor survival [101,102].

The tumor suppressor miRNAs are generally downregulated in cancer cells, including PCa cells, and promote proliferation, metastasis, and cell invasiveness. In PCa miR-143, miR-145, and members of the miR-200 family play a major role in cell migration and tumorigenesis due to the fact that their downregulation activates epithelial-mesenchymal transition (EMT) $[103,104]$. EMT is a process through which epithelial cells assume the features of mesenchymal stem cells, able to differentiate in a broad range of cells, thus acquiring invasive and migratory properties. This effect seems to be mediated by the activation of the translation factors zinc-finger E-box binding homeobox 1 and 2 (ZEB1 and ZEB2) [105]. miR-29b, miR-205, miR-940, and miR-218 downregulation in PCa is related to an increase in cell invasiveness and migration, together with an increase in mesenchymal phenotype of prostate cells $[101,103,106]$.

Other miRNAs, such as miR-15a and miR-16, target important oncogenes, such as Bcl2, Mcl1, CCnd1, and Wnt3, all involved in apoptosis induction. In PCa, these miRNAs are generally downregulated, favoring the inhibition of apoptosis and tumor progression. The pleiotropic effects exerted by tumor suppressor miRNAs include the modulation of androgen receptor (AR) genes expression (miR-488*, miR-125b, miR-155a, miR-27a) and cell proliferation stimulation (miR-497, miR-296-5p). Loss of miR-101 in PCa cells modifies histone methylation and, consequently, gene expression [101]. Another important miRNA in PCa cells is miR-195. Its abnormal expression has been related to poor survival of PCa. MiR-195 has been shown to bind to, and target, the 3' untranslated region of the clusterin (CLU) gene, thus regulating docetaxel resistance of PCa cells [107]. CLU is a secreted glycoprotein found to be involved in neurodegeneration, aging, and cancer. The specific role of CLU in tumorigenesis is still a matter of debate, as its expression has been found altered (i.e., upregulated or downregulated) in different kinds of cancer. Downregulation of CLU in naïve cancers is, by far, the prevailing condition that is found. CLU may be tumor-suppressive at the initial stages of carcinogenesis and tumor-permissive at late stages or in therapy-resistant cancers [108]. CLU is downregulated in human PCa progression and during the development of PCa in the transgenic adenocarcinoma of the mouse prostate (TRAMP) model [109]. Its expression is restored in TRAMP mice responding to chemoprevention with green tea catechins [41]. Knocking down CLU in the TRAMP model generated a more aggressive kind of PCa [110]. The silencing of CLU expression in the TRAMP model promoted activation of NF- $\mathrm{KB}$ and transcriptional upregulation and increased activity of MMP-2 and MMP-9 [111].

The let-7 family members of miRNAs function as tumor suppressors: let-7a and let-7c are generally downregulated in PCa and positively impact the cell proliferation rate [101].

\subsubsection{Long Noncoding RNA (lncRNA)}

Recently, several studies have focused on the importance of noncoding RNAs on genome dynamic expression. The protein-coding RNAs constitute less than $2 \%$ of the human genome, meaning that the majority of the human transcriptome produces RNAs that are not translated into proteins. IncRNAs have a length of more than 200 nucleotides, most are polyadenylated, transcribed by RNA polymerase II, and able to bind DNA, RNA, and proteins. More targeted research is being done on lncRNAs due to the fact that different regulatory roles of these molecules have been demonstrated. Epigenetic modulation is the most common method of lncRNAs regulation of gene expression, and it generally results in transcriptional repression. LncRNAs cooperate with polycomb repressive complexes (PRC) to control the transcriptional machinery activity. Other mechanisms by which lncRNAs modulate gene expression involve mRNA processing through alteration of transcript stability, processing and translation, interaction with miRNAs, gene enhancers and repressors, or transcription factors affecting transcript production and transport. In this way, IncRNAs can act as oncogenes or tumor suppressors, 
thus influencing important cellular processes. Many lncRNAs are over-, or under-expressed in PCa, where they have been found to interact with and modulate AR signaling or to affect fundamental cell pathways. The molecular mechanisms of lncRNAs in PCa progression and their potential role as biomarkers or therapeutic targets need to be explored more deeply [112,113]. Nevertheless, flavonoids have been found as lncRNA modulators in different cancer cell types [114].

\section{Flavonoids as Epigenetic Modulators in Prostate Cancer}

The pleiotropic effects exerted by flavonoids in PCa cells can also be explained by epigenetic changes in gene expression and chromatin organization. Epigenetic alterations have been identified as key initiating events frequently occurring in several cancers. In this part of the review, we will focus on the ability of flavonoids to restore the "normal epigenetic marks" that are often altered in tumor cells. This feature is the reason why epigenetic therapy as a promising treatment option for multiple cancer types.

\subsection{Flavones}

Apigenin is a natural flavone (4',5,7-trihydroxyflavone) that is present in high quantities in grapefruits, onions, parsley, and chamomile [115]. The growth inhibitory effects found in cancer cells after apigenin administration have been attributed to multiple mechanisms of action. Apigenin affects cell cycle regulation, apoptosis, immune response stimulation, and cell migration. Many pathways have been found to be modulated by this flavone, including PI3K/protein kinase B (Akt) MAPK/ERK, Janus kinases (JAKs), signal transducer and activator of transcription proteins (STATs) (JAK/STAT), NF-кB, and $W n t / \beta$-catenin [116].

PCa, PC3, and 22Rv1 cells, exposed to 20 and $40 \mu \mathrm{M}$ of apigenin for $24 \mathrm{~h}$, showed a decrease of HDAC activity comparable to that obtained using the well-known HDAC inhibitor trichostatin (TSA). Specifically, apigenin caused the downregulation of HDAC1 and HDAC3, both at the protein and mRNA levels, with a concomitant increase of the acetylation of $\mathrm{H} 3$ and $\mathrm{H} 4$. As a consequence, this enhanced the accessibility of DNA promoters to transcription factors, increasing the synthesis of the cell cycle regulator protein p21/waf1 in PCa cells [50]. p21/waf1 controls cell cycle progression primarily through inhibition of cyclin-dependent kinase 2 (CDK-2) (Figure 2).

It is a common target for HDAC inhibitors (HDACi). PCa cells showed cell cycle arrest and apoptotic pathway induction after $24 \mathrm{~h}$ of apigenin administration [50]. In vivo studies conducted on PC3 xenografts in athymic nude mice confirmed the antitumoral action of apigenin. An oral intake of 20 and $50 \mathrm{mg} / \mathrm{mouse} / \mathrm{d}$ over a period of eight weeks caused a marked decrease of HDAC activity, and HDAC1 and HDAC3 protein expression also decreased as well as a reduction in tumor growth. In apigenin-fed mice, p21/waf1 expression was higher than in control mice, and bax/bcl2 ratio shifted towards the induction of apoptosis [50]. In vitro and in vivo experiments demonstrated the pleiotropic effects of apigenin in different PCa models: a reduction of HDACs, ROS production enhancement, attenuation of NF-kB pathway, and caspase activation are only a few examples of the action mediated by this flavone, whose action is selective only towards cancer cells and does not affect normal cells [117]. The efficacy of apigenin as a single agent improves when administered in a combinatorial therapeutic approach with other chemotherapeutic agents or with other HDAC inhibitors. Recent results showed that apigenin synergistically potentiates tumor necrosis factor-related apoptosis by inducing ligand (TRAIL)-induced apoptosis in DU145 cells [117].

Luteolin ( $3^{\prime}, 4^{\prime}, 5^{\prime}, 7^{\prime}$-tetrahydroxyflavone) belongs to the flavonoid group. Its structure is very similar to quercetin, although, compared to quercetin, it is a less efficient radical scavenger. Luteolin has two benzene rings and a third ring containing oxygen. It is found in onion, broccoli, carrots, peppers, and apple skin [118] and exhibits a wide range of beneficial properties, including anticancer activity [119-121]. Luteolin modulates various signaling pathways involved in carcinogenesis [122,123]. 


\section{flavonoids}

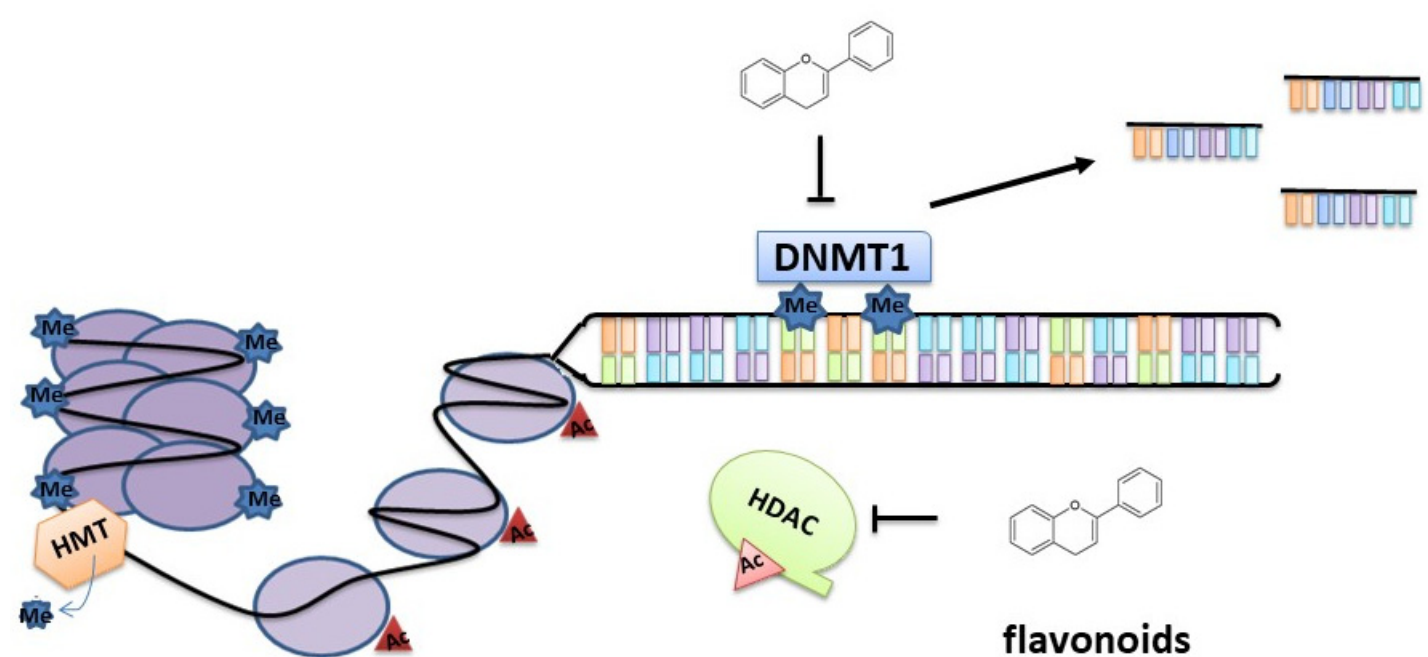

Figure 2. Epigenetic mechanisms of flavonoid action. Flavonoids (apigenin, silibinin, catechins) can act as histone deacetylase (HDAC) inhibitors by promoting the transcriptional expression of genes involved in cell cycle arrest and apoptosis induction. Flavonoids (genistein, catechins) promote the downregulation of DNA methyltransferase (DNMT)1 that leads to the demethylation, and consequent reactivation, of methylation-silenced genes.

PC3 and LNCaP cells treated with 10-60 $\mu \mathrm{M}$ of luteolin for 24, 48, and $72 \mathrm{~h}$ showed a marked dose-dependent reduction of cell proliferation and induction of apoptosis. The Authors noticed that 16 kinds of miRNA were down or upregulated in PCa cells exposed to luteolin. Specifically, the Authors focused on miR-301, which was found to be the most downregulated oncogenic miRNA after luteolin administration. The pro-apoptotic factor death effector domain containing 2 (DEDD2), a putative important mediator for death receptors, was indicated as a target of miR-301. The mRNA and protein levels of DEDD2 were found to have increased more than two times with miR-301 in both PCa cells [121].

Sakurai et al. described the co-administration of luteolin and/or gefitinib to human PCa PC3 cells as having had a greater effect on cell viability than the administration of either compound alone. The treatment was associated with a significant decrease of the expression of cyclin G-associated kinase (GAK), which has an important role in clathrin-mediated membrane trafficking and is often overexpressed in cancer cells. The downregulation of GAK is mediated by the upregulation of miR-630, which is associated to hyper-phosphorylation of tyrosine residues in epidermal growth factor receptor (EGFR) and alters the downstream signaling [124].

When luteolin binds to type $\mathrm{II}^{3} \mathrm{H}$-estradiol binding sites, identified as histone $\mathrm{H} 4$, the proliferation of normal and tumor prostate cells is inhibited in vitro and in vivo. Luteolin blocks the acetylation of histone $\mathrm{H} 4$ and regulates the expression of c-FOS, p21, and other genes playing key roles in the epidermal growth factor receptor signaling pathway and in cell cycle regulation [125].

Morin (3,5,7,20,40-pentahydroxyflavone) is a flavonoid isolated from plants belonging to the Moraceae family. Its structure is constituted by two aromatic rings linked by an oxygen-containing heterocycle. Morin administration induces apoptosis and was found to have anti-tumoral effects in several cancer cell lines [126-128].

In LNCaP (human PCa cells), morin at a concentration of 50 and $75 \mu \mathrm{M}$ induced apoptosis and cell proliferation arrest after 24 and $48 \mathrm{~h}$, respectively [129,130].

In a recent report, morin was shown to dysregulate the expression of several miRNAs, including miR-143, miR-146b, and miR-155 in PC3 and DU145 cells. 
Specifically, the most effective result was the suppression of miR-155 after cell treatment with $50 \mu \mathrm{M}$ of morin. The treatment of morin and/or paclitaxel led to the recovery of the expression of GATA binding protein 3 (GATA3) through inhibition of miR-155 [131]. In normal prostate, GATA3 is highly expressed, and it is involved in the regulation of prostate-specific antigen (PSA) genes, whereas, during cancer progression, its expression is gradually reduced. The treatment of PCa cells with morin caused an increase of GATA3 expression and a decrease of zinc finger E-box-binding homeobox 2 (ZEB2), transforming growth factor beta 1 (TGFB1), and murine double minute 2 (MDM2) levels. The chemo-sensitivity of PCa cells to paclitaxal is increased by morin addition, resulting in restoring the miR-155-suppressed expression of GATA3 [131].

Tricin (4',5,7-Trihydroxy-3' , $^{\prime}$-dimethoxyflavone) is a flavonoid with important beneficial effects for human health. It exhibited anti-oxidant activities, a protective action for liver function, and was effective against the flu virus [132]. A recent study reported the synergistic anti-proliferative effect of docetaxel $(0.01 \mathrm{nM})$ and tricin $(60 \mu \mathrm{M})$ on human PCa PC3 cells. Although the mechanism of action of this natural compound requires more investigation, the Authors found a significant decrease in miR-21 expression $48 \mathrm{~h}$ after the treatment of PC3 cells with 120 and $140 \mu \mathrm{M}$ of Tricin. Mir-21 is generally overexpressed in men with metastatic PCa or resistant to docetaxel [133].

\subsection{Flavonols}

Quercetin is categorized as a flavonol. It has a hydroxyl group in $3,5,7,3^{\prime}$ and $4^{\prime}$ position. It is found in a variety of foods, such as apples, berries, onions, grapes, capers, tea, and tomatoes [134].

Quercetin has different intracellular molecular targets and affects multiple signaling processes that are altered in cancer cells by exerting anti-inflammatory, anti-oxidant, and anti-microbic effects.

Quercetin has been shown to slow down carcinogenesis through inhibition of a pro-proliferative signaling pathway, both in animal models and in human cancer cell lines [135-137].

Several studies have demonstrated that quercetin modulates the expression and the activity of several epigenetic enzymes, such as DNMTs, HATs, and nuclear HDACs [138]. The treatment of quercetin has also been found to reduce dose-dependent activity of some histone phosphorylases, such as aurora kinase (AURKA) A, B, and C, which are involved in the progression of the cell cycle [138].

A recent study by Yang et al. showed that the combination of quercetin and hyperoside (quercetin-3-O-galactoside), a flavonoid compound extracted from Hypericum perforatum, has a strong anticancer effect on PCa cells [139]. A possible mechanism responsible for growth arrest and the inhibition of metastatic spread involves the regulation of miR-21 expression in PC 3 cells. CLU, whose expression is downregulated in PCa cells, has been identified as one of the targets of miR-21 in head and neck squamous cell carcinoma [140]. Quercetin and hyperoside administration lead to a decrease of oncomir miR-21 expression, with a resulting increase in the translation of target proteins like PDCD4. PDCD4 inhibits growth promotion through the suppression of the transactivation of the AP-1 promoter via c-Jun [141] and through the inhibition of the eukaryotic initiation factor 4A activity $[139,142]$.

\subsection{Flavanones}

Silibinin is a natural flavonolignan. It is the most active compound of silymarin, a standardized extract from the seeds of milk thistle (Silybum marianum). Silibinin is composed of silybin A and silybin B, two diastereoisomers of almost equimolar concentration. Along with the stereoisomers dihydrosilybin, isosilybin, silychristin, and silydianin, silibinin represents the most abundant component of silymarin [143]. Silibinin affects multiple signaling and regulatory mechanisms and exhibits anti-tumor efficacy in many cancer types in vitro and in vivo. In PCa, it has been shown to inhibit tumor progression affecting cell proliferation, epithelial-mesenchymal transition, invasion, metastasis, angiogenesis, and apoptosis [143]. In a recent study, silibinin administration at concentrations of $25-75 \mu \mathrm{g} / \mathrm{mL}$ for $48 \mathrm{~h}$ was shown to reduce the expression levels of enhancer of zeste homolog 2 (EZH2), embryonic ectoderm development (EED), and suppressor of zeste homolog 12 (SUZ12), in DU145 and PC3 PCa cells. These proteins are components of the polycomb repressive 
complex 2 (PRC2), which has histone methyltransferase activity and catalyzes the methylation (adding one, two or three methyl groups) of histone 3 at lysine 27 (H3K27me1, 2, and 3). H3K27me3 is recognized as a hallmark of heterochromatin, which targets repressed genes. Silibinin treatment of PCa cells led to a strong decrease of EZH2 expression with a concomitant increase of the H3K27me3 levels; this effect can be explained by the modulation of the levels of Akt and its activated phosphorylated form (pAkt). pAkt phosphorylates the ser21 of EZH2, thus reducing the affinity of EZH2 for histone $\mathrm{H} 3$ with a consequent drop of H3K27me3. EZH2 is generally overexpressed in metastatic PCa cells and in patients with poor prognosis $[144,145]$. EZH2 protein controls other mechanisms of gene transcriptional repression, such as DNMT binding and HDAC recruitment. Furthermore, the effect of silibinin results in a modest increase of DNMT activity and a decrease in HDAC1 and HDAC2 expression levels, both actions leading to inhibition of gene expression [144].

\subsection{Isoflavonoids}

Genistein is the most biologically active isoflavone present in soybeans. It has been found to have in vivo and in vitro anticancer effects and anti-proliferative effects on several types of human cancers, including PCa [146,147].

Genistein has a human $17 \beta$-estradiol-like structure, and for this reason, it binds to the estrogen receptor, which is highly expressed in prostate epithelial cells, causing estrogenic and/or antiestrogenic effects [148]. The mechanisms through which genistein inhibits PCa progression involve different signaling pathways [149-151]. Genistein-dependent demethylating activity in cancer has recently been studied. Mahmoud et al. clearly showed that physiological doses of genistein $(0.5-10 \mu \mathrm{M})$ significantly reduced the methylation levels of estrogen receptor (ER)- $\beta$ promoter, resulting in increase in ER- $\beta$ expression and induction of ER- $\beta$ transcriptional activity in human PCa LNCaP and LAPC-4 cells. In PC3 cells, the effect was most likely not the same due to the low basal level of ER- $\beta$ promoter methylation. Data reported by the research group indicated that a decline in DNMT1 and DNMT3b levels, without a change in DNMT3a levels, has been evidenced after genistein treatment. These enzymes, which are responsible for methyl group transfer to cytosine residues, were downregulated after $48 \mathrm{~h}$ of genistein administration and reverted tumor suppressor gene ER- $\beta$ hypermethylation in PCa [152] (Figure 1).

In another study, a DNA microarray analysis was used to analyze the expression profile of genistein-treated PC3 and DU145 cells [153] versus controls. Results showed that genistein inhibited PCa cell growth through upregulation of tumor suppressor miR-34a, which directly targets HOX Transcript Antisense RNA (HOTAIR), a lncRNA that regulates key pathways in PCa invasion and metastasis [153]. A few recent studies focused on the interaction between miRNAs and lncRNAs in human cancer cells [154-157]. HOTAIR can function as a scaffold through binding and directing EZH2 and Lysine (K)-specific demethylase 1A (LSD1) to occupy the same genomic regions. It can also accelerate proteolysis through the facilitation of E3 ubiquitin ligases binding to their substrates. HOTAIR was also found to be an androgen-repressed lncRNA that can directly bind to AR to protect it from degradation in PCa. In castration-resistant PCa cells, where AR and androgen-repressed genes are upregulated, HOTAIR is present at higher expression levels in comparison to normal cells [158].

\subsection{Catechins}

Catechins are natural polyphenolic compounds belonging to the flavonoid family that are abundantly found in a variety of vegetables and fruits as well as in plant-based beverages. Green tea is the main dietary source of catechins [159]. Catechins, which account for more than $10 \%$ of the green tea leaves' weight, are considered the compounds to which most of the beneficial effects of green tea can be ascribed $[15,35,160]$. Epigallocatechin-gallate (EGCG) is the most abundant (at least $50 \%$ of the total catechin content) and the most biologically active catechin present in green tea extracts. Many clinical studies have demonstrated the anti-proliferative, anti-oxidant, and anti-cancer effect of EGCG and, more generally, of a green tea catechins mixture [161], given pure or in combination 
with other natural compounds [162,163]. Although the anti-tumoral effects of EGCG have clearly been recognized, the molecular mechanism of action of catechins needs more investigation. As with many other natural compounds, catechins can also modulate epigenetic changes in gene expression and chromatin remodeling, as affects mainly DNA methylation and histone acetylation status [164-168]. EGCG has been reported to act on DNMTs, HDACs, and HATs expression levels and activity in different cancer cells, including PCa [169].

EGCG, at a concentration of $20 \mu \mathrm{M}$ for $48 \mathrm{~h}$, has been shown to competitively inhibit DNMT1 activity, causing demethylation of $\mathrm{CPG}$ islands and reactivation of methylation-silenced genes in human PCa PC3 cells [165]. Moreover, EGCG has been demonstrated to suppress androgen-dependent PCa cells growth and proliferation. Regulation of prostate cell proliferation and apoptosis appears to be modulated by androgen receptor (AR) acetylation [170]. AR, a hormone nuclear receptor that mediates androgen action in prostate cells, is regulated by HATs acetylation [170]. EGCG inhibited acetylation-dependent AR translocation to the nucleus in LNCaP cells [171]. Similarly, EGCG-treated mice bearing a 22Rv1 PCa cell xenograft showed a decrease in AR protein expression. EGCG was found to interfere with AR stability decreasing interdomain interactions, causing the inhibition of the transactivation functions and decreasing the expression of AR. These alterations were concomitant with an inhibition of miR-21 and an upregulation of miR-330, which acts as a tumor suppressor that is able to induce apoptosis of PCa cells in EGCG-treated mice in comparison to untreated controls [172].

In many studies, green tea catechins are administered in vivo or in vitro in the form of a standardized green catechins extract, called Polyphenon E, composed of EGCG $(65 \%)$, EGC $(4 \%)$, epicatechin (9\%), epicatechin-3-gallate $(6 \%)$, gallocatechin-3-gallate $(4 \%)$, catechin-3-gallate $(0.2 \%)$, gallocatechin $(0.2 \%)$, catechins $(1.1 \%)$, and caffeine $(0.7 \%)$. A concentration of $10 \mu \mathrm{g} / \mathrm{mL}$ of Polyphenon E given to cell cultures roughly corresponds to $14.0 \mu \mathrm{M}$ of EGCG.

Polyphenon E administered to LNCaP and PC3 cells for $24 \mathrm{~h}$ at a concentration of $10-80 \mu \mathrm{g} / \mathrm{mL}$ resulted in class I HDAC inhibition: the decrease in HDAC activity leads to hyperacetylation of histone $\mathrm{H} 3$ on the p21/waf1 and Bax promoters. These events are associated with cell cycle arrest and apoptotic death induction [173].

Exposure of human PCa LNCaP cells to $1-10 \mu \mathrm{g} / \mathrm{mL}$ of Polyphenon E for 1 to 7 days provoked the downregulation of DNMT1 mRNA and protein expression, which caused a reversal in glutathione-S-transferase P1 (GSTP1) CpG island hypermethylation and restoration of GSTP1 expression [174].

In a recent paper by Deb et al., green tea polyphenols were shown to inhibit the migration and invasion of PCa cells by reactivation of epigenetically silenced tissue inhibitor of metalloproteinase 3 (TIMP-3) and subsequent inhibition of metalloproteinases (MMPs) activity. MMPs, such as MMP-2 and MMP-9, are produced as inactive forms (pro-MMP) that need to be activated by cleavage to promote tumor cell migration. MMPs and TIMPs co-operate and regulate tumor progression. Recent studies suggest that epigenetic mechanisms regulate MMP-2 and MMP-9 activation, as well as genes involved in TIMPs control [175-178]. Human PCa DUPRO and LNCaP cells treated for $72 \mathrm{~h}$ with $10 \mu \mathrm{g} / \mathrm{mL}$ Polyphenon E or $20 \mu \mathrm{M}$ EGCG showed an induction of TIMP-3 mRNA and protein. TIMP-3 expression was associated with downregulation of H3K27me3 (repressive histone mark) at the TIMP-3 promoter and an increase of $\mathrm{H} 3 \mathrm{~K} 9 / 18$ acetylation (transcription active histone signature) in human $\mathrm{PCa}$ cells. In green tea catechins treated cells, the Authors demonstrated a decrease in EZH2 and HDAC protein levels. Similar results have been described in tissue specimens obtained from PCa patients supplemented with Polyphenon E. In this clinical trial, patients received a total of $1.3 \mathrm{~g}$ of Polyphenon E during a six-week interval between prostate biopsy and radical prostatectomy [178].

\subsection{Anthocyanidins}

Delphinidin is one of the main anthocyanidins, characterized by a diphenylpropane skeleton. It is abundantly found in pigmented fruits and vegetables, such as pomegranates, berries, grapes, beets, and eggplants $[179,180]$. It exhibits anti-oxidant, anti-inflammatory, anti-angiogenic, and anti-cancer 
properties in different types of tumor cells [18,44]. In human PCa LNCaP cells, delphinidin administration ( $100 \mu \mathrm{M}$ for $24 \mathrm{~h}$ ) was found to increase the expression of active caspases. The active caspases led to HDAC3 cleavage, and HDAC3 inactivation resulted in p53 acetylation, activation, and oligomerization. The p53 protein activates important pro-apoptotic genes and plays a crucial role in the maintenance of genomic stability, thus inhibiting the growth of cancer cells. HDAC3 cleavage results in the p53-dependent induction of the expression of the pro-apoptotic proteins p21 and Bax [181].

Results are summarized in Table 2.

Table 2. Targets and cellular mechanism of flavonoids in prostate cancer (PCa). Flavonoids that exert anti-tumoral effect in PCa through epigenetic mechanisms are reported in the table. See text for details.

\begin{tabular}{|c|c|c|c|c|c|}
\hline & & $\begin{array}{l}\text { Cell Lines/Animal } \\
\text { Models/Clinical Trials }\end{array}$ & Molecular Target & Cellular Mechanism & Ref \\
\hline \multirow{7}{*}{ Flavones } & Apigenin & PC3-22Rv1 cells & $\begin{array}{l}\downarrow \mathrm{HDAC} 1, \mathrm{HDAC} 3 \\
\uparrow \text { acetylation H3-H4 }\end{array}$ & $\begin{array}{l}\text { Cell cycle arrest } \\
\text { apoptosis }\end{array}$ & [50] \\
\hline & & PC3 xenograft mice & $\downarrow$ HDAC1, HDAC3 & Tumor growth reduction & {$[50]$} \\
\hline & Luteolin & PC3-LNCaP cells & $\downarrow$ miR-301 & $\begin{array}{l}\text { Inhibition proliferation } \\
\text { apoptosis }\end{array}$ & [121] \\
\hline & +/- gefitinib & PC3 cells & $\uparrow \mathrm{miR}-603$ & $\begin{array}{l}\text { Growth arrest } \\
\text { Apoptosis }\end{array}$ & [124] \\
\hline & & PC3 cells & Binding to $\mathrm{H} 4$ & Cell cycle arrest & [125] \\
\hline & $\begin{array}{l}\text { Morin } \\
+ \text { paclitaxel }\end{array}$ & $\begin{array}{l}\text { DU145, PC3 cells } \\
\text { DU145 xenograft mice }\end{array}$ & $\begin{array}{l}\downarrow \mathrm{miR}-155 \\
\downarrow \mathrm{miR}-155\end{array}$ & $\begin{array}{l}\text { Apoptosis } \\
\text { Suppression of PCa } \\
\text { progression }\end{array}$ & [131] \\
\hline & $\begin{array}{l}\text { Tricin } \\
+ \text { docetaxel }\end{array}$ & PC3 cells & $\downarrow \mathrm{miR}-21$ & Inhibition proliferation & [133] \\
\hline Flavonols & $\begin{array}{l}\text { Quercetin } \\
+ \text { hyperoside }\end{array}$ & PC3 cells & $\downarrow \mathrm{miR}-21$ & $\begin{array}{l}\text { Apoptosis, cell cycle } \\
\text { arrest and reduced } \\
\text { invasive capacity }\end{array}$ & [139] \\
\hline Flavanones & Silibinin & DU145, PC3 cells & $\begin{array}{l}\downarrow \mathrm{EZH} 2, \uparrow \text { DNMT } \\
\downarrow \text { HDAC1, HDAC2 }\end{array}$ & $\begin{array}{l}\text { Cell cycle arrest } \\
\text { Apoptosis }\end{array}$ & [144] \\
\hline \multirow[t]{2}{*}{ Isoflavonoids } & Genistein & LNCaP, LAPC-4 cells & $\downarrow$ DNMT1, DNMT3b & Inhibition proliferation & [152] \\
\hline & & PC3, DU145 cells & $\begin{array}{l}\uparrow \operatorname{miR}-34 a, \downarrow \\
\text { HOTAIR }\end{array}$ & $\begin{array}{l}\text { Cell cycle arrest } \\
\text { Apoptosis } \\
\text { Inibition proliferation }\end{array}$ & [153] \\
\hline \multirow{6}{*}{ Catechins } & EGCG & PC3 cells & $\downarrow$ DNMT & Cell growth inhibition & [165] \\
\hline & EGCG & LNCaP cells & $\downarrow \mathrm{HAT}$ & Cell growth inhibition & [171] \\
\hline & EGCG & $\begin{array}{l}\text { LNCaP 22Rv1 cells } \\
\text { 22Rv1 xenograft mice }\end{array}$ & $\begin{array}{l}\downarrow \mathrm{AR} \\
\downarrow \mathrm{AR}, \mathrm{miR}-21, \uparrow \\
\mathrm{miR}-330\end{array}$ & $\begin{array}{l}\text { Cell growth inhibition } \\
\text { Suppression of } \mathrm{PCa} \\
\text { progression }\end{array}$ & [172] \\
\hline & Polyphenon E & LNCaP, PC3 cells & $\begin{array}{l}\downarrow \text { HDAC1, HDAC2, } \\
\text { HDAC3, HDAC8 } \\
\uparrow \text { acetylation H3 }\end{array}$ & $\begin{array}{l}\text { Cell cycle arrest } \\
\text { Apoptosis }\end{array}$ & [173] \\
\hline & Polyphenon E & LNCaP cells & $\downarrow$ DNMT1 & Growth arrest & [174] \\
\hline & $\begin{array}{l}\text { Polyphenon } \\
\text { E/EGCG }\end{array}$ & $\begin{array}{l}\text { DUPRO, LNCaP cells } \\
\text { Patients undergoing } \\
\text { prostatectomy }\end{array}$ & $\begin{array}{l}\downarrow \mathrm{HDAC} 1, \mathrm{EZH} 2 \\
\downarrow \mathrm{HDAC} 1\end{array}$ & $\begin{array}{l}\text { Migration, invasion } \\
\text { abrogation } \\
\text { Suppression of PCa } \\
\text { progression }\end{array}$ & [178] \\
\hline \multicolumn{2}{|c|}{ Anthocyanidins Delphinidin } & LNCaP cell lines & $\downarrow$ HDAC3 & apoptosis & [181] \\
\hline
\end{tabular}




\section{Conclusion and Perspectives}

In this review, we overviewed the most recent evidence of the antitumoral effects exerted by dietary flavonoids, with a special focus on their ability to employ epigenetic regulation by modulating epigenetic enzyme activities in PCa. Epigenetic alterations were identified as key initiating events in several kinds of cancer. For this reason, epigenetic therapy is currently considered a valid strategy to inhibit carcinogenesis. Natural compounds are a pool of active molecules with a wide range of biological effects, including the epigenetic modulation of gene expression, which deserves further investigation. Many dietary flavonoids were found to reverse DNA aberrations that promote neoplastic transformation, particularly in the case of PCa. The epigenetic targets of flavonoid action include oncogenes and tumor suppressor genes, which are indirectly controlled through the regulation of epigenetic enzymes such as DNMTs, HATs, and HDACs. In particular, many flavonoids, such as apigenin, silibinin, and catechins, were found to be active at downregulating HDACs expression, mostly HDAC 1 and HDAC3. Downregulation occurs at both mRNA and protein levels, thus promoting the transcriptional expression of genes involved in cell cycle arrest and apoptosis induction. Other flavonoids, such as genistein or catechins, promote the downregulation of DNMT1 that leads to demethylation, and consequent reactivation, of methylation-silenced genes. In addition, flavonoids were found capable of interacting with miRNAs and lncRNAs. These are very important RNAs that modulate the expression of several genes and may cause the dysregulation of important cellular processes when their expression is altered during diseases. In particular, miR-21 is one of the most studied oncomirs, and represents a target for many flavonoids, including tricin, quercetin, and catechins. The downregulation of miR-21 expression promoted by flavonoids administration promotes cell cycle inhibition and the induction of apoptotic death of tumor cells; the pleiotropic effects of flavonoids may be explained by the regulation of the cascade triggered by miRNAs and lncRNAs.

Another promising issue is the combination of natural flavonoids with chemotherapeutic agents to potentiate the effect of pharmacological agents. This approach may have the potential to provide novel and more efficient strategies to fight cancer. To this end, it is necessary to better understand the epigenetic mechanisms and the players involved in the onset and progression of cancer by performing more clinical trials with flavonoids, compounds which are generally well tolerated by patients at low dosages. Further studies are also necessary to increase the understanding of flavonoids action in aggressive PCa and in PCa cells resistant to therapies. Dosage in vivo and the length of time for which cells are exposed to flavonoids may make the difference. Cancer cells may be sensitive to flavonoids activity when treated in specific "windows of opportunity", which we should identify and take into account for the optimization of their use as natural epigenetic modulators for the chemoprevention, and possibly the treatment, of PCa and other kinds of cancer.

Author Contributions: S.I., V.N., and S.B. critically reviewed the literature and wrote the manuscript. All authors have read and agreed to the published version of the manuscript.

Funding: This research received no external funding.

Conflicts of Interest: The authors declare no conflict of interest.

\section{References}

1. Bray, F.; Ferlay, J.; Soerjomataram, I.; Siegel, R.L.; Torre, L.A.; Jemal, A. Global cancer statistics 2018: GLOBOCAN estimates of incidence and mortality worldwide for 36 cancers in 185 countries. CA Cancer J. Clin. 2018, 68, 394-424. [CrossRef]

2. Ziglioli, F.; Granelli, G.; Cavalieri, D.M.; Bocchialini, T.; Maestroni, U. What chance do we have to decrease prostate cancer overdiagnosis and overtreatment? A narrative review. Acta Biomed. 2019, 90, 423-426. [PubMed]

3. Chen, F.Z.; Zhao, X.K. Prostate cancer: Current treatment and prevention strategies. Iran. Red Crescent Med. J. 2013, 15, 279-284. [CrossRef] [PubMed] 
4. Karantanos, T.; Corn, P.G.; Thompson, T.C. Prostate cancer progression after androgen deprivation therapy: Mechanisms of castrate resistance and novel therapeutic approaches. Oncogene 2013, 32, 5501-5511. [CrossRef] [PubMed]

5. Damber, J.E.; Aus, G. Prostate cancer. Lancet 2008, 371, 1710-1721. [CrossRef]

6. Fromont, G.; Yacoub, M.; Valeri, A.; Mangin, P.; Vallancien, G.; Cancel-Tassin, G.; Cussenot, O. Differential expression of genes related to androgen and estrogen metabolism in hereditary versus sporadic prostate cancer. Cancer Epidemiol. Biomark. Prev. 2008, 17, 1505-1509. [CrossRef]

7. Alberti, C. Hereditary/familial versus sporadic prostate cancer: Few indisputable genetic differences and many similar clinicopathological features. Eur. Rev. Med. Pharmacol. Sci. 2010, 14, 31-41.

8. Baade, P.D.; Youlden, D.R.; Krnjacki, L.J. International epidemiology of prostate cancer: Geographical distribution and secular trends. Mol. Nutr. Food Res. 2009, 53, 171-184. [CrossRef]

9. Kheirandish, P.; Chinegwundoh, F. Ethnic differences in prostate cancer. Br. J. Cancer 2011, 105, $481-485$. [CrossRef]

10. Shimizu, H.; Ross, R.K.; Bernstein, L.; Henderson, B.E.; Mack, T.M.; Yatani, R. Cancers of the prostate and breast among japanese and white immigrants in los angeles county. Br. J. Cancer 1991, 63, 963-966. [CrossRef]

11. Lee, J.; Demissie, K.; Lu, S.E.; Rhoads, G.G. Cancer incidence among Korean-American immigrants in the United States and native Koreans in South Korea. Cancer Control 2007, 11, 78-85. [CrossRef] [PubMed]

12. Sacco, E.; Vaccarella, L.; Bientinesi, R.; Gandi, C. Lifestyle in urology: Cancer. Urol. J. 2019, 86, $105-114$.

13. Klein, E.A.; Thompson, I.M. Chemoprevention of prostate cancer: An updated view. World J. Urol. 2012, 30, 189-194. [CrossRef] [PubMed]

14. Tombal, B. Chemoprevention of prostate cancer. In Management of Prostate Cancer: A Multidisciplinary Approach; Van Poppel, B., Ed.; Springer: Berlin/Heidelberg, Germany, 2012; pp. 13-24. ISBN 9783642275975.

15. Khan, N.; Mukhtar, H. Tea polyphenols for health promotion. Life Sci. 2007, 81, 519-533. [CrossRef] [PubMed]

16. Arts, I.C.W.; Hollman, P.C.H. Polyphenols and disease risk in epidemiologic studies. Am. J. Clin. Nutr. 2005, 81, 317S-325S. [CrossRef]

17. Pandey, K.B.; Rizvi, S.I. Plant polyphenols as dietary antioxidants in human health and disease. Oxid. Med. Cell. Longev. 2009, 2, 270-278. [CrossRef]

18. Albarracin, S.L.; Stab, B.; Casas, Z.; Sutachan, J.J.; Samudio, I.; Gonzalez, J.; Gonzalo, L.; Capani, F.; Morales, L.; Barreto, G.E. Effects of natural antioxidants in neurodegenerative disease. Nutr. Neurosci. 2012, 15, 1-9. [CrossRef]

19. Zhang, H.; Tsao, R. Dietary polyphenols, oxidative stress and antioxidant and anti-inflammatory effects. Curr. Opin. Food Sci. 2016, 8, 33-42. [CrossRef]

20. Scalbert, A.; Johnson, I.T.; Saltmarsh, M. Polyphenols: Antioxidants and beyond. Am. J. Clin. Nutr. 2005, 81, 215S-217S. [CrossRef]

21. Singh, R.P.; Agarwal, R. Mechanisms of action of novel agents for prostate cancer chemoprevention. Endocr. Relat. Cancer 2006, 13, 751-778. [CrossRef]

22. Ignat, I.; Volf, I.; Popa, V.I. A critical review of methods for characterisation of polyphenolic compounds in fruits and vegetables. Food Chem. 2011, 126, 1821-1835. [CrossRef]

23. Kaurinovic, B.; Vastag, D. Flavonoids and Phenolic Acids as Potential Natural Antioxidants. In Antioxidants; IntechOpen: London, UK, 2019. [CrossRef]

24. Panche, A.N.; Diwan, A.D.; Chandra, S.R. Flavonoids: An overview. J. Nutr. Sci. 2016, 5, e47. [CrossRef] [PubMed]

25. Kumar, S.; Pandey, A.K. Chemistry and biological activities of flavonoids: An overview. Sci. World J. 2013, 213, 162750. [CrossRef] [PubMed]

26. Hollman, P.C.H.; Bijsman, M.N.C.P.; Van Gameren, Y.; Cnossen, E.P.J.; De Vries, J.H.M.; Katan, M.B. The sugar moiety is a major determinant of the absorption of dietary flavonoid glycosides in man. Free Radic. Res. 1999, 31, 569-573. [CrossRef] [PubMed]

27. Darband, S.G.; Kaviani, M.; Yousefi, B.; Sadighparvar, S.; Pakdel, F.G.; Attari, J.A.; Mohebbi, I.; Naderi, S.; Majidinia, M. Quercetin: A functional dietary flavonoid with potential chemo-preventive properties in colorectal cancer. J. Cell. Physiol. 2018, 233, 6544-6560. [CrossRef] [PubMed]

28. Sudhakaran, M.; Sardesai, S.; Doseff, A.I. Flavonoids: New frontier for immuno-regulation and breast cancer control. Antioxidants 2019, 8, 103. [CrossRef] 
29. Rodríguez-García, C.; Sánchez-Quesada, C.; Gaforio, J.J.; Gaforio, J.J. Dietary flavonoids as cancer chemopreventive agents: An updated review of human studies. Antioxidants 2019, 8, 137. [CrossRef]

30. Lotito, S.B.; Frei, B. Consumption of flavonoid-rich foods and increased plasma antioxidant capacity in humans: Cause, consequence, or epiphenomenon? Free Radic. Biol. Med. 2006, 41, 1727-1746. [CrossRef]

31. Cutler, G.J.; Nettleton, J.A.; Ross, J.A.; Harnack, L.J.; Jacobs, D.R.; Scrafford, C.G.; Barraj, L.M.; Mink, P.J.; Robien, K. Dietary flavonoid intake and risk of cancer in postmenopausal women: The Iowa Women's Health Study. Int. J. Cancer 2008, 123, 664-671. [CrossRef]

32. Sak, K. Current epidemiological knowledge about the role of flavonoids in prostate carcinogenesis. Exp. Oncol. 2017, 39, 98-105. [CrossRef]

33. Miyata, Y.; Shida, Y.; Hakariya, T.; Sakai, H. Anti-cancer effects of green tea polyphenols against prostate cancer. Molecules 2019, 24, 193. [CrossRef] [PubMed]

34. Reale, G.; Russo, G.I.; Di Mauro, M.; Regis, F.; Campisi, D.; Giudice, A.L.; Marranzano, M.; Ragusa, R.; Castelli, T.; Cimino, S.; et al. Association between dietary flavonoids intake and prostate cancer risk: A case-control study in Sicily. Complement. Ther. Med. 2018, 39, 14-18. [CrossRef] [PubMed]

35. Bettuzzi, S.; Brausi, M.; Rizzi, F.; Castagnetti, G.; Peracchia, G.; Corti, A. Chemoprevention of human prostate cancer by oral administration of green tea catechins in volunteers with high-grade prostate intraepithelial neoplasia: A preliminary report from a one-year proof-of-principle study. Cancer Res. 2006, 66, 1234-1240. [CrossRef]

36. Brausi, M.; Rizzi, F.; Bettuzzi, S. Chemoprevention of Human Prostate Cancer by Green Tea Catechins: Two Years Later. A Follow-up Update. Eur. Urol. 2008, 54, 472-473. [CrossRef] [PubMed]

37. Lee, P.M.Y.; Ng, C.F.; Liu, Z.M.; Ho, W.M.; Lee, M.K.; Wang, F.; Kan, H.D.; He, Y.H.; Ng, S.S.M.; Wong, S.Y.S.; et al. Reduced prostate cancer risk with green tea and epigallocatechin 3-gallate intake among Hong Kong Chinese men. Prostate Cancer Prostatic Dis. 2017, 20, 318-322. [CrossRef]

38. D'Archivio, M.; Filesi, C.; Di Benedetto, R.; Gargiulo, R.; Giovannini, C.; Masella, R. Polyphenols, dietary sources and bioavailability. Annali-Istituto Superiore Sanita 2007, 43, 348-361.

39. Van Duynhoven, J.; Vaughan, E.E.; Jacobs, D.M.; Kemperman, R.A.; Van Velzen, E.J.J.; Gross, G.; Roger, L.C.; Possemiers, S.; Smilde, A.K.; Doré, J.; et al. Metabolic fate of polyphenols in the human superorganism. Proc. Natl. Acad. Sci. USA 2011, 108 (Suppl. S1), 4531-4538. [CrossRef]

40. Chen, Z.; Zheng, S.; Li, L.; Jiang, H. Metabolism of Flavonoids in Human: A Comprehensive Review. Curr. Drug Metab. 2014, 15, 48-61. [CrossRef]

41. Caporali, A.; Davalli, P.; Astancolle, S.; D'Arca, D.; Brausi, M.; Bettuzzi, S.; Corti, A. The chemopreventive action of catechins in the TRAMP mouse model of prostate carcinogenesis is accompanied by clusterin over-expression. Carcinogenesis 2004, 25, 2217-2224. [CrossRef]

42. Skibola, C.F.; Smith, M.T. Potential health impacts of excessive flavonoid intake. Free Radic. Biol. Med. 2000, 29, 375-383. [CrossRef]

43. Vogiatzoglou, A.; Mulligan, A.A.; Lentjes, M.A.H.; Luben, R.N.; Spencer, J.P.E.; Schroeter, H.; Khaw, K.T.; Kuhnle, G.G.C. Flavonoid intake in European adults (18 to 64 Years). PLoS ONE 2015, 10, e0128132. [CrossRef]

44. Lall, R.K.; Syed, D.N.; Adhami, V.M.; Khan, M.I.; Mukhtar, H. Dietary polyphenols in prevention and treatment of prostate cancer. Int. J. Mol. Sci. 2015, 16, 3350-3376. [CrossRef] [PubMed]

45. Veluri, R.; Singh, R.P.; Liu, Z.; Thompson, J.A.; Agarwal, R.; Agarwal, C. Fractionation of grape seed extract and identification of gallic acid as one of the major active constituents causing growth inhibition and apoptotic death of DU145 human prostate carcinoma cells. Carcinogenesis 2006, 27, 1445-1453. [CrossRef] [PubMed]

46. Kwon, G.T.; Jung, J.I.; Song, H.R.; Woo, E.Y.; Jun, J.G.; Kim, J.K.; Her, S.; Park, J.H.Y. Piceatannol inhibits migration and invasion of prostate cancer cells: Possible mediation by decreased interleukin- 6 signaling. J. Nutr. Biochem. 2012, 27, 1445-1453. [CrossRef] [PubMed]

47. Wang, T.T.Y.; Schoene, N.W.; Kim, Y.S.; Mizuno, C.S.; Rimando, A.M. Differential effects of resveratrol and its naturally occurring methylether analogs on cell cycle and apoptosis in human androgen-responsive LNCaP cancer cells. Mol. Nutr. Food Res. 2010, 54, 335-344. [CrossRef]

48. Dorai, T.; Gehani, N.; Katz, A. Therapeutic potential of curcumin in human prostate cancer-I. Curcumin induces apoptosis in both androgen-dependent and androgen-independent prostate cancer cells. Prostate Cancer Prostatic Dis. 2000, 3, 84-93. [CrossRef] 
49. Dorai, T.; Cao, Y.C.; Dorai, B.; Buttyan, R.; Katz, A.E. Therapeutic potential of curcumin in human prostate cancer. III. Curcumin inhibits proliferation, induces apoptosis, and inhibits angiogenesis of LNCaP prostate cancer cells in vivo. Prostate 2001, 47, 293. [CrossRef]

50. Pandey, M.; Kaur, P.; Shukla, S.; Abbas, A.; Fu, P.; Gupta, S. Plant flavone apigenin inhibits HDAC and remodels chromatin to induce growth arrest and apoptosis in human prostate cancer cells: In vitro and in vivo study. Mol. Carcinog. 2012, 51, 952-962. [CrossRef]

51. Hagen, R.M.; Chedea, V.S.; Mintoff, C.P.; Bowler, E.; Morse, H.R.; Ladomery, M.R. Epigallocatechin-3-gallate promotes apoptosis and expression of the caspase 9a splice variant in PC3 prostate cancer cells. Int. J. Oncol. 2013, 43, 194-200. [CrossRef]

52. Siddique, N.A.; Mujeeb, M.; Najmi, A.K.; Khan, H.N.; Farooqi, H. WITHDRAWN: Evaluation of antioxidant activity, quantitative estimation of phenols and flavonoids in different parts of Aegle marmelos. J. Saudi Chem. Soc. 2010, 4, 1-5. [CrossRef]

53. Koksal, E.; Bursal, E.; Dikici, E.; Tozoglu, F.; Gulcin, I. Antioxidant activity of Melissa officinalis leaves. J. Med. Plants Res. 2011, 5, 217-222.

54. Pietta, P.G. Flavonoids as antioxidants. J. Nat. Prod. 2000, 63, 1035-1042. [CrossRef] [PubMed]

55. Robak, J.; Gryglewski, R.J. Flavonoids are scavengers of superoxide anions. Biochem. Pharmacol. 1988, 37, 837-841. [CrossRef]

56. Birt, D.F.; Hendrich, S.; Wang, W. Dietary agents in cancer prevention: Flavonoids and isoflavonoids. Pharmacol. Ther. 2001, 90, 157-177. [CrossRef]

57. Costea, T.; Nagy, P.; Ganea, C.; Szöllősi, J.; Mocanu, M.M. Molecular mechanisms and bioavailability of polyphenols in prostate cancer. Int. J. Mol. Sci. 2019, 20, 1062. [CrossRef] [PubMed]

58. Chaudhary, A.; Pechan, T.; Willett, K.L. Differential protein expression of peroxiredoxin I and II by benzo(a)pyrene and quercetin treatment in 22Rv1 and PrEC prostate cell lines. Toxicol. Appl. Pharmacol. 2007, 210, 197-210. [CrossRef] [PubMed]

59. Sorrenti, V.; Vanella, L.; Acquaviva, R.; Cardile, V.; Giofrè, S.; Di Giacomo, C. Cyanidin induces apoptosis and differentiation in prostate cancer cells. Int. J. Oncol. 2015, 47, 1303-1310. [CrossRef]

60. Eghbaliferiz, S.; Iranshahi, M. Prooxidant Activity of Polyphenols, Flavonoids, Anthocyanins and Carotenoids: Updated Review of Mechanisms and Catalyzing Metals. Phyther. Res. 2016, 30, 1379-1391. [CrossRef]

61. Ward, A.B.; Mir, H.; Kapur, N.; Gales, D.N.; Carriere, P.P.; Singh, S. Quercetin inhibits prostate cancer by attenuating cell survival and inhibiting anti-apoptotic pathways. World J. Surg. Oncol. 2018, 16, 108. [CrossRef]

62. Bode, A.M.; Dong, Z. Signal transduction and molecular targets of selected flavonoids. Antioxid. Redox Signal. 2013, 19, 163-180. [CrossRef]

63. Kang, N.J.; Lee, K.W.; Kwon, J.Y.; Hwang, M.K.; Rogozin, E.A.; Heo, Y.S.; Bode, A.M.; Lee, H.J.; Dong, Z. Delphinidin attenuates neoplastic transformation in JB6 Cl41 mouse epidermal cells by blockingraf/mitog en-activated protein kinase kinase/extracellular signal-regulated kinase signaling. Cancer Prev. Res. 2008, 20, 522-531. [CrossRef] [PubMed]

64. Lee, K.W.; Kang, N.J.; Rogozin, E.A.; Kim, H.G.; Cho, Y.Y.; Bode, A.M.; Lee, H.J.; Surh, Y.J.; Bowden, G.T.; Dong, Z. Myricetin is a novel natural inhibitor of neoplastic cell transformation and MEK1. Carcinogenesis 2007, 28, 1918-1927. [CrossRef] [PubMed]

65. Ki, W.L.; Nam, J.K.; Heo, Y.S.; Rogozin, E.A.; Pugliese, A.; Mun, K.H.; Bowden, G.T.; Bode, A.M.; Hyong, J.L.; Dong, Z. Raf and MEK protein kinases are direct molecular targets for the chemopreventive effect of quercetin, a major flavonol in red wine. Cancer Res. 2008, 68, 946-955.

66. Byun, S.; Lee, K.W.; Jung, S.K.; Lee, E.J.; Hwang, M.K.; Lim, S.H.; Bode, A.M.; Lee, H.J.; Dong, Z. Luteolin inhibits protein kinase $C \varepsilon$ and c-Src activities and UVB-induced skin cancer. Cancer Res. 2010, 70, 2415-2423. [CrossRef] [PubMed]

67. Sung, K.J.; Ki, W.L.; Byun, S.; Nam, J.K.; Sung, H.L.; Heo, Y.S.; Bode, A.M.; Bowden, G.T.; Hyong, J.L.; Dong, Z. Myricetin suppresses UVB-induced skin cancer by targeting Fyn. Cancer Res. 2008, 68, 6021-6029.

68. Dan, H.C.; Cooper, M.J.; Cogswell, P.C.; Duncan, J.A.; Ting, J.P.Y.; Baldwin, A.S. Akt-dependent regulation of NF-кB is controlled by mTOR and Raptor in association with IKK. Genes Dev. 2008, 22, 1490-1500. [CrossRef]

69. Kim, W.; Yang, H.J.; Youn, H.; Yun, Y.J.; Seong, K.M.; Youn, B. Myricetin Inhibits Akt Survival Signaling and Induces Bad-mediated Apoptosis in a Low Dose Ultraviolet (UV)-B-irradiated HaCaT Human Immortalized Keratinocytes. J. Radiat. Res. 2010, 51, 285-296. [CrossRef] 
70. Jung, S.K.; Lee, K.W.; Byun, S.; Lee, E.J.; Kim, J.E.; Bode, A.M.; Dong, Z.; Lee, H.J. Myricetin inhibits UVB-induced angiogenesis by regulating PI-3 kinase in vivo. Carcinogenesis 2009, 31, 911-917. [CrossRef]

71. Kwon, J.Y.; Lee, K.W.; Kim, J.E.; Jung, S.K.; Kang, N.J.; Hwang, M.K.; Heo, Y.S.; Bode, A.M.; Dong, Z.; Lee, H.J. Delphinidin suppresses ultraviolet B-induced cyclooxygenases-2 expression through inhibition of MAPKK4 and PI-3 kinase. Carcinogenesis 2009, 30, 1932-1940. [CrossRef]

72. Guo, Z.; Hu, X.; Xing, Z.; Xing, R.; Lv, R.; Cheng, X.; Su, J.; Zhou, Z.; Xu, Z.; Nilsson, S.; et al. Baicalein inhibits prostate cancer cell growth and metastasis via the caveolin-1/AKT/mTOR pathway. Mol. Cell. Biochem. 2015, 406, 111-119. [CrossRef]

73. Erdogan, S.; Doganlar, O.; Doganlar, Z.B.; Serttas, R.; Turkekul, K.; Dibirdik, I.; Bilir, A. The flavonoid apigenin reduces prostate cancer CD44+ stem cell survival and migration through PI3K/Akt/NF- $\mathrm{B}$ signaling. Life Sci. 2016, 162, 77-86. [CrossRef] [PubMed]

74. Shukla, S.; Bhaskaran, N.; Babcook, M.A.; Fu, P.; MacLennan, G.T.; Gupta, S. Apigenin inhibits prostate cancer progression in TRAMP mice via targeting PI3K/Akt/FoxO pathway. Carcinogenesis 2014, 35, 452-460. [CrossRef] [PubMed]

75. Zhu, Y.; Wu, J.; Li, S.; Wang, X.; Liang, Z.; Xu, X.; Xu, X.; Hu, Z.; Lin, Y.; Chen, H.; et al. Apigenin inhibits migration and invasion via modulation of epithelial mesenchymal transition in prostate cancer. Mol. Med. Rep. 2015, 11, 1004-1008. [CrossRef] [PubMed]

76. Rizzi, F.; Naponelli, V.; Silva, A.; Modernelli, A.; Ramazzina, I.; Bonacini, M.; Tardito, S.; Gatti, R.; Uggeri, J.; Bettuzzi, S. Polyphenon $\mathrm{E}^{\circledR}$, a standardized green tea extract, induces endoplasmic reticulum stress, leading to death of immortalized PNT1a cells by anoikis and tumorigenic PC3 by necroptosis. Carcinogenesis 2014, 35, 828-839. [CrossRef] [PubMed]

77. Liu, K.C.; Yen, C.Y.; Wu, R.S.C.; Yang, J.S.; Lu, H.F.; Lu, K.W.; Lo, C.; Chen, H.Y.; Tang, N.Y.; Wu, C.C.; et al. The roles of endoplasmic reticulum stress and mitochondrial apoptotic signaling pathway in quercetin-mediated cell death of human prostate cancer PC-3 cells. Environ. Toxicol. 2014, 29, 428-439. [CrossRef] [PubMed]

78. Abotaleb, M.; Samuel, S.M.; Varghese, E.; Varghese, S.; Kubatka, P.; Liskova, A.; Büsselberg, D. Flavonoids in cancer and apoptosis. Cancers 2019, 11, 28. [CrossRef] [PubMed]

79. Chowdhury, S.A.; Kishino, K.; Satoh, R.; Hashimoto, K.; Kikuchi, H.; Nishikawa, H.; Shirataki, Y.; Sakagami, H. Tumor-specificity and apoptosis-inducing activity of stilbenes and flavonoids. Anticancer Res. 2005, 25, 2055-2063.

80. Shukla, S.; Gupta, S. Apigenin-induced prostate cancer cell death is initiated by reactive oxygen species and p53 activation. Free Radic. Biol. Med. 2008, 44, 1833-1845. [CrossRef]

81. Szliszka, E.; Helewski, K.J.; Mizgala, E.; Krol, W. The dietary flavonol fisetin enhances the apoptosis-inducing potential of TRAIL in prostate cancer cells. Int. J. Oncol. 2011, 39, 771-779.

82. Wang, P.; Heber, D.; Henning, S.M. Quercetin increased the antiproliferative activity of green tea polyphenol (-)-epigallocatechin gallate in prostate cancer cells. Nutr. Cancer 2012, 64, 580-587. [CrossRef]

83. Sharma, S.; Kelly, T.K.; Jones, P.A. Epigenetics in cancer. Carcinogenesis 2009, 31, 27-36. [CrossRef] [PubMed]

84. Bredfeldt, T.G.; Walker, C.L. Epigenetics. In Comprehensive Toxicology, 2nd ed.; Elsevier Science: Oxford, UK, 2010; ISBN 9780080468846.

85. Albany, C.; Alva, A.S.; Aparicio, A.M.; Singal, R.; Yellapragada, S.; Sonpavde, G.; Hahn, N.M. Epigenetics in Prostate Cancer. Prostate Cancer 2011. [CrossRef] [PubMed]

86. Mukherjee, N.; Kumar, A.P.; Ghosh, R. DNA Methylation and Flavonoids in Genitourinary Cancers. Curr. Pharmacol. Rep. 2015, 1, 112-120. [CrossRef] [PubMed]

87. Sasaki, M. Methylation and Inactivation of Estrogen, Progesterone, and Androgen Receptors in Prostate Cancer. J. Natl. Cancer Inst. 2002, 94, 384-390. [CrossRef]

88. Lodygin, D.; Epanchintsev, A.; Menssen, A.; Diebold, J.; Hermeking, H. Functional epigenomics identifies genes frequently silenced in prostate cancer. Cancer Res. 2005, 65, 4218-4227. [CrossRef]

89. Li, L.C.; Carroll, P.R.; Dahiya, R. Epigenetic changes in prostate cancer: Implication for diagnosis and treatment. J. Natl. Cancer Inst. 2005, 97, 103-115. [CrossRef]

90. Sathyanarayana, U.G.; Padar, A.; Suzuki, M.; Maruyama, R.; Shigematsu, H.; Hsieh, J.T.; Frenkel, E.P.; Gazdar, A.F. Aberrant Promoter Methylation of Laminin-5-Encoding Genes in Prostate Cancers and Its Relationship to Clinicopathological Features. Clin. Cancer Res. 2003, 9, 6395-6400. 
91. Li, L.C.; Zhao, H.; Nakajima, K.; Oh, B.R.; Alves Ribeiro Filho, L.; Carroll, P.; Dahiya, R. Methylation of the E-cadherin gene promoter correlates with progression of prostate cancer. J. Urol. 2001, 166, 705-709. [CrossRef]

92. Alumkal, J.J.; Zhang, Z.; Humphreys, E.B.; Bennett, C.; Mangold, L.A.; Carducci, M.A.; Partin, A.W.; Garrett-Mayer, E.; DeMarzo, A.M.; Herman, J.G. Effect of DNA Methylation on Identification of Aggressive Prostate Cancer. Urology 2008, 72, 1234-1239. [CrossRef]

93. Carvalho, J.R.; Filipe, L.; Costa, V.L.; Ribeiro, F.R.; Martins, A.T.; Teixeira, M.R.; Jerónimo, C.; Henrique, R. Detailed analysis of expression and promoter methylation status of apoptosis-related genes in prostate cancer. Apoptosis 2010, 15, 956-965. [CrossRef]

94. Jurkowska, R.Z.; Jurkowski, T.P.; Jeltsch, A. Structure and Function of Mammalian DNA Methyltransferases. ChemBioChem 2011, 12, 206-222. [CrossRef] [PubMed]

95. Yegnasubramanian, S.; Haffner, M.C.; Zhang, Y.; Gurel, B.; Cornish, T.C.; Wu, Z.; Irizarry, R.A.; Morgan, J.; Hicks, J.; DeWeese, T.L.; et al. DNA Hypomethylation Arises Later in Prostate Cancer Progression than CpG Island Hypermethylation and Contributes to Metastatic Tumor Heterogeneity. Cancer Res. 2008, 68, 8954-8967. [CrossRef] [PubMed]

96. Nowacka-Zawisza, M.; Wiśnik, E. DNA methylation and histone modifications as epigenetic regulation in prostate cancer (review). Oncol. Rep. 2017, 38, 2587-2596. [CrossRef] [PubMed]

97. Chervona, Y.; Costa, M. Histone modifications and cancer: Biomarkers of prognosis? Am. J. Cancer Res. 2012, 2, 589-597.

98. Kurdistani, S.K. Histone modifications in cancer biology and prognosis. Prog. Drug Res. 2011, 67, 91-106.

99. Bonner, W.M.; Redon, C.E.; Dickey, J.S.; Nakamura, A.J.; Sedelnikova, O.A.; Solier, S.; Pommier, Y. $\gamma H 2 A X$ and cancer. Nat. Rev. Cancer 2008, 8, 957-967. [CrossRef]

100. Nanni, S.; Priolo, C.; Grasselli, A.; D’Eletto, M.; Merola, R.; Moretti, F.; Gallucci, M.; De Carli, P.; Sentinelli, S.; Cianciulli, A.M.; et al. Epithelial-restricted gene profile of primary cultures from human prostate tumors: A molecular approach to predict clinical behavior of prostate cancer. Mol. Cancer Res. 2006, 4, 79-92. [CrossRef]

101. Kanwal, R.; Plaga, A.R.; Liu, X.; Shukla, G.C.; Gupta, S. MicroRNAs in prostate cancer: Functional role as biomarkers. Cancer Lett. 2017, 4, 350-357. [CrossRef]

102. Walter, B.A.; Valera, V.A.; Pinto, P.A.; Merino, M.J. Comprehensive microRNA profiling of prostate cancer. J. Cancer 2013, 99, 445-450. [CrossRef]

103. Josson, S.; Chung, L.W.K.; Gururajan, M. MicroRNAs and prostate cancer. In Advances in Experimental Medicine and Biology; SpringerNature: Basel, Switzerland, 2015; pp. 105-118.

104. Sekhon, K.; Bucay, N.; Majid, S.; Dahiya, R.; Saini, S. MicroRNAs and epithelial-mesenchymal transition in prostate cancer. Oncotarget 2016, 7, 67597-67611. [CrossRef]

105. Chen, Y.; Zhang, L. Members of the microRNA-200 family are promising therapeutic targets in cancer (Review). Exp. Ther. Med. 2017, 14, 10-17. [CrossRef] [PubMed]

106. Mekhail, S.M.; Yousef, P.G.; Jackinsky, S.W.; Pasic, M.; Yousef, G.M. miRNA in Prostate Cancer: New Prospects for Old Challenges. EJIFCC 2014, 25, 79-98. [PubMed]

107. Ma, X.; Zou, L.; Li, X.; Chen, Z.; Lin, Q.; Wu, X. MicroRNA-195 regulates docetaxel resistance by targeting clusterin in prostate cancer. Biomed. Pharmacother. 2018, 99, 445-450. [CrossRef] [PubMed]

108. Rizzi, F.; Bettuzzi, S. The clusterin paradigm in prostate and breast carcinogenesis. Endocr. Relat. Cancer 2010, 17, R1-R17. [CrossRef]

109. Scaltriti, M.; Brausi, M.; Amorosi, A.; Caporali, A.; D’Arca, D.; Astancolle, S.; Corti, A.; Bettuzzi, S. Clusterin (SGP-2, ApoJ) expression is downregulated in low- and high-grade human prostate cancer. Int. J. Cancer 2004, 108, 23-30. [CrossRef]

110. Bettuzzi, S.; Davalli, P.; Davoli, S.; Chayka, O.; Rizzi, F.; Belloni, L.; Pellacani, D.; Fregni, G.; Astancolle, S.; Fassan, M.; et al. Genetic inactivation of ApoJ/clusterin: Effects on prostate tumourigenesis and metastatic spread. Oncogene 2009, 28, 4344-4352. [CrossRef]

111. Bonacini, M.; Negri, A.; Davalli, P.; Naponelli, V.; Ramazzina, I.; Lenzi, C.; Bettuzzi, S.; Rizzi, F. Clusterin Silencing in Prostate Cancer Induces Matrix Metalloproteinases by an NF-B-Dependent Mechanism. J. Oncol. 2019, 266, 16425-16430. [CrossRef] 
112. Ramnarine, V.R.; Kobelev, M.; Gibb, E.A.; Nouri, M.; Lin, D.; Wang, Y.; Buttyan, R.; Davicioni, E.; Zoubeidi, A.; Collins, C.C. The evolution of long noncoding RNA acceptance in prostate cancer initiation, progression, and its clinical utility in disease management. Eur. Urol. 2019, 31, 11050-11058. [CrossRef]

113. Malik, B.; Feng, F. Long noncoding RNAs in prostate cancer: Overview and clinical implications. Asian J. Androl. 2016, 18, 568-574.

114. Saghafi, T.; Ali Taheri, R.; Parkkila, S.; Emameh, R.Z. Phytochemicals as modulators of long non-coding RNAs and inhibitors of cancer-related carbonic anhydrases. Int. J. Mol. Sci. 2019, 20, 2939. [CrossRef]

115. Shukla, S.; Gupta, S. Apigenin: A promising molecule for cancer prevention. Pharm. Res. 2010, $27,962-978$. [CrossRef] [PubMed]

116. Yan, X.; Qi, M.; Li, P.; Zhan, Y.; Shao, H. Apigenin in cancer therapy: Anti-cancer effects and mechanisms of action. Cell Biosci. 2017, 7, 50. [CrossRef] [PubMed]

117. Ganai, S.A. Plant-derived flavone Apigenin: The small-molecule with promising activity against therapeutically resistant prostate cancer. Biomed. Pharmacother. 2017, 85, 47-56. [CrossRef]

118. Lin, Y.; Shi, R.; Wang, X.; Shen, H.-M. Luteolin, a Flavonoid with Potential for Cancer Prevention and Therapy. Curr. Cancer Drug Targets 2008, 8, 634-646. [CrossRef]

119. Lu, J.; Li, G.; He, K.; Jiang, W.; Xu, C.; Li, Z.; Wang, H.; Wang, W.; Wang, H.; Teng, X.; et al. Luteolin exerts a marked antitumor effect in cMet-overexpressing patient-derived tumor xenograft models of gastric cancer. J. Transl. Med. 2015, 13, 42. [CrossRef] [PubMed]

120. Ma, L.; Peng, H.; Li, K.; Zhao, R.; Li, L.; Yu, Y.; Wang, X.; Han, Z. Luteolin exerts an anticancer effect on NCI-H460 human non-small cell lung cancer cells through the induction of Sirt1-mediated apoptosis. Mol. Med. Rep. 2015, 12, 4196-4202. [CrossRef] [PubMed]

121. Han, K.; Meng, W.; Zhang, J.J.; Zhou, Y.; Wang, Y.L.; Su, Y.; Lin, S.C.; Gan, Z.H.; Sun, Y.N.; Min, D.L. Luteolin inhibited proliferation and induced apoptosis of prostate cancer cells through miR-301. Onco Targets Ther. 2016, 9, 3085-3094. [CrossRef]

122. Kim, Y.S.; Kim, S.H.; Shin, J.; Harikishore, A.; Lim, J.K.; Jung, Y.; Lyu, H.N.; Baek, N.I.; Choi, K.Y.; Yoon, H.S.; et al. Luteolin suppresses cancer cell proliferation by targeting vaccinia-related kinase 1. PLoS ONE 2014, 9, e109655. [CrossRef]

123. Hong, Z.; Cao, X.; Li, N.; Zhang, Y.; Lan, L.; Zhou, Y.; Pan, X.; Shen, L.; Yin, Z.; Luo, L. Luteolin is effective in the non-small cell lung cancer model with L858R/T790M EGF receptor mutation and erlotinib resistance. Br. J. Pharmacol. 2014, 171, 2842-2853. [CrossRef]

124. Sakurai, M.A.; Ozaki, Y.; Okuzaki, D.; Naito, Y.; Sasakura, T.; Okamoto, A.; Tabara, H.; Inoue, T.; Hagiyama, M.; Ito, A.; et al. Gefitinib and luteolin cause growth arrest of human prostate cancer PC-3 cells via inhibition of cyclin G-associated kinase and induction of miR-630. PLoS ONE 2014, 9, e100124. [CrossRef]

125. Markaverich, B.M.; Vijjeswarapu, M. Multiple sites of type II site ligand (Luteolin and BMHPC) regulation of gene expression in PC-3 cells. Int. J. Biomed. Sci. 2012, 8, 219-232. [PubMed]

126. Jin, H.; Lee, W.S.; Eun, S.Y.; Jung, J.H.; Park, H.S.; Kim, G.; Choi, Y.H.; Ryu, C.H.; Jung, J.M.; Hong, S.C.; et al. Morin, a flavonoid from Moraceae, suppresses growth and invasion of the highly metastatic breast cancer cell line MDA-MB-231 partly through suppression of the Akt pathway. Int. J. Oncol. 2014, 45, 1629-1637. [CrossRef] [PubMed]

127. Gupta, S.C.; Phromnoi, K.; Aggarwal, B.B. Morin inhibits STAT3 tyrosine 705 phosphorylation in tumor cells through activation of protein tyrosine phosphatase SHP1. Biochem. Pharmacol. 2013, 85, 898-912. [CrossRef] [PubMed]

128. Park, C.; Lee, W.S.; Go, S., II; Nagappan, A.; Han, M.H.; Hong, S.H.; Kim, G.S.; Kim, G.Y.; Kwon, T.K.; Ryu, C.H.; et al. Morin, a flavonoid from moraceae, induces apoptosis by induction of bad protein in human leukemic cells. Int. J. Mol. Sci. 2015, 16, 645-659. [CrossRef] [PubMed]

129. Romero, I.; Páez, A.; Ferruelo, A.; Luján, M.; Berenguer, A. Polyphenols in red wine inhibit the proliferation and induce apoptosis of LNCaP cells. BJU Int. 2002, 89, 950-954. [CrossRef] [PubMed]

130. Ferruelo, A.; Romero, I.; Cabrera, P.M.; Arance, I.; Andrés, G.; Angulo, J.C. Effects of resveratrol and other wine polyphenols on the proliferation, apoptosis and androgen receptor expression in LNCaP cells. Actas Urológicas Españolas 2014, 38, 397-404. [CrossRef]

131. Li, B.; Jin, X.; Meng, H.; Hu, B.; Zhang, T.; Yu, J.; Chen, S.; Guo, X.; Wang, W.; Jiang, W.; et al. Morin promotes prostate cancer cells chemosensitivity to paclitaxel through miR-155/GATA3 axis. Oncotarget 2017, 8, 47849-47860. [CrossRef] 
132. Moheb, A.; Grondin, M.; Ibrahim, R.K.; Roy, R.; Sarhan, F. Winter wheat hull (husk) is a valuable source for tricin, a potential selective cytotoxic agent. Food Chem. 2013, 138, 931-937. [CrossRef]

133. Ghasemi, S.; Lorigooini, Z.; Wibowo, J.P.; Amini-khoei, H. Tricin isolated from Allium atroviolaceum potentiated the effect of docetaxel on PC3 cell proliferation: Role of miR-21. Nat. Prod. Res. 2019, 33, 1828-1831. [CrossRef]

134. Li, Y.; Yao, J.; Han, C.; Yang, J.; Chaudhry, M.T.; Wang, S.; Liu, H.; Yin, Y. Quercetin, inflammation and immunity. Nutrients 2016, 8, 167. [CrossRef]

135. Stepani, V.; Novak, R.; Gall, K. Epigenome, Cancer Prevention and Flavonoids and Curcumin. In Epigenetics and Epigenomics; InTech: Rijeka, Croatia, 2014; pp. 173-210.

136. ElAttar, T.M.A.; Virji, A.S. Modulating effect of resveratrol and quercetin on oral cancer cell growth and proliferation. Anticancer Drugs 1999, 10, 187-193. [CrossRef] [PubMed]

137. Richter, M.; Ebermann, R.; Marian, B. Quercetin-induced apoptosis in colorectal tumor cells: Possible role of EGF receptor signaling. Nutr. Cancer 1999, 34, 88-99. [CrossRef] [PubMed]

138. Kedhari Sundaram, M.; Hussain, A.; Haque, S.; Raina, R.; Afroze, N. Quercetin modifies 5'CpG promoter methylation and reactivates various tumor suppressor genes by modulating epigenetic marks in human cervical cancer cells. J. Cell. Biochem. 2019, 120, 18357-18369. [CrossRef] [PubMed]

139. Yang, F.Q.; Liu, M.; Li, W.; Che, J.P.; Wang, G.C.; Zheng, J.H. Combination of quercetin and hyperoside inhibits prostate cancer cell growth and metastasis via regulation of microRNA-21. Mol. Med. Rep. 2015, 11, 1085-1092. [CrossRef] [PubMed]

140. Mydlarz, W.; Uemura, M.; Ahn, S.; Hennessey, P.; Chang, S.; Demokan, S.; Sun, W.; Shao, C.; Bishop, J.; Krosting, J.; et al. Clusterin is a gene-specific target of microrna-21 in head and neck squamous cell carcinoma. Clin. Cancer Res. 2014, 20, 868-877. [CrossRef] [PubMed]

141. Bitomsky, N.; Böhm, M.; Klempnauer, K.H. Transformation suppressor protein Pdcd4 interferes with JNK-mediated phosphorylation of c-Jun and recruitment of the coactivator p300 by c-Jun. Oncogene 2004, 23, 7484-7493. [CrossRef]

142. Yang, H.-S.; Jansen, A.P.; Komar, A.A.; Zheng, X.; Merrick, W.C.; Costes, S.; Lockett, S.J.; Sonenberg, N.; Colburn, N.H. The Transformation Suppressor Pdcd4 Is a Novel Eukaryotic Translation Initiation Factor 4A Binding Protein That Inhibits Translation. Mol. Cell. Biol. 2003, 23, 26-37. [CrossRef]

143. Ting, H.; Deep, G.; Agarwal, R. Molecular mechanisms of silibinin-mediated cancer chemoprevention with major emphasis on prostate cancer. AAPS J. 2013, 15, 707-716. [CrossRef]

144. Anestopoulos, I.; Sfakianos, A.P.; Franco, R.; Chlichlia, K.; Panayiotidis, M.I.; Kroll, D.J.; Pappa, A. A novel role of silibinin as a putative epigenetic modulator in human prostate carcinoma. Molecules 2017, $22,62$. [CrossRef]

145. Ellinger, J.; Kahl, P.; Von Der Gathen, J.; Heukamp, L.C.; Gütgemann, I.; Walter, B.; Hofstädter, F.; Bastian, P.J.; Von Ruecker, A.; Müller, S.C.; et al. Global histone H3K27 methylation levels are different in localized and metastatic prostate cancer. Cancer Investig. 2012, 30, 92-97. [CrossRef]

146. De Souza, P.L.; Russell, P.J.; Kearsley, J.H.; Howes, L.G. Clinical pharmacology of isoflavones and its relevance for potential prevention of prostate cancer. Nutr. Rev. 2010, 68, 542-555. [CrossRef]

147. Hwang, Y.W.; Kim, S.Y.; Jee, S.H.; Kim, Y.N.; Nam, C.M. Soy food consumption and risk of prostate cancer: A meta-analysis of observational studies. Nutr. Cancer 2009, 61, 598-606. [CrossRef]

148. Kuiper, G.G.J.M.; Lemmen, J.G.; Carlsson, B.; Corton, J.C.; Safe, S.H.; Van Der Saag, P.T.; Van Der Burg, B.; Gustafsson, J.Å. Interaction of estrogenic chemicals and phytoestrogens with estrogen receptor $\beta$. Endocrinology 1998, 139, 4252-4263. [CrossRef]

149. Yan, G.R.; Yin, X.F.; Xiao, C.L.; Tan, Z.L.; Xu, S.H.; He, Q.Y. Identification of novel signaling components in genistein-regulated signaling pathways by quantitative phosphoproteomics. J. Proteom. 2011, 75, 695-707. [CrossRef]

150. Li, Y.; Sarkar, F.H. Inhibition of nuclear factor $\kappa B$ activation in PC3 cells by genistein is mediated via Akt signaling pathway. Clin. Cancer Res. 2002, 8, 2369-2377.

151. Liss, M.A.; Schlicht, M.; Kahler, A.; Fitzgerald, R.; Thomassi, T.; Degueme, A.; Hessner, M.; Datta, M.W. Characterization of soy-based changes in Wnt-frizzled signaling in prostate cancer. Cancer Genom. Proteom. 2010, 7, 245-252. 
152. Mahmoud, A.M.; Al-Alem, U.; Ali, M.M.; Bosland, M.C. Genistein increases estrogen receptor beta expression in prostate cancer via reducing its promoter methylation. J. Steroid Biochem. Mol. Biol. 2015, 152, 62-75. [CrossRef]

153. Chiyomaru, T.; Yamamura, S.; Fukuhara, S.; Yoshino, H.; Kinoshita, T.; Majid, S.; Saini, S.; Chang, I.; Tanaka, Y.; Enokida, H.; et al. Genistein Inhibits Prostate Cancer Cell Growth by Targeting miR-34a and Oncogenic HOTAIR. PLoS ONE 2013, 8, e70372. [CrossRef]

154. Hansen, T.B.; Wiklund, E.D.; Bramsen, J.B.; Villadsen, S.B.; Statham, A.L.; Clark, S.J.; Kjems, J. MiRNA-dependent gene silencing involving Ago2-mediated cleavage of a circular antisense RNA. EMBO J. 2011, 30, 4414-4422. [CrossRef]

155. Braconi, C.; Kogure, T.; Valeri, N.; Huang, N.; Nuovo, G.; Costinean, S.; Negrini, M.; Miotto, E.; Croce, C.M.; Patel, T. MicroRNA-29 can regulate expression of the long non-coding RNA gene MEG3 in hepatocellular cancer. Oncogene 2011, 30, 4750-4756. [CrossRef]

156. Li, X.; Chen, G.; Zhang, X.; Zhang, Q.; Zheng, S.; Wang, G.; Chen, Q.H. A new class of flavonol-based anti-prostate cancer agents: Design, synthesis, and evaluation in cell models. Bioorg. Med. Chem. Lett. 2016, 26, 4241-4245. [CrossRef] [PubMed]

157. Ye, Y.; Li, S.L.; Wang, S.Y. Construction and analysis of mRNA, miRNA, lncRNA, and TF regulatory networks reveal the key genes associated with prostate cancer. PLoS ONE 2018, 13, e0198055. [CrossRef] [PubMed]

158. Zhang, A.; Zhao, J.C.; Kim, J.; Fong, K.W.; Yang, Y.A.; Chakravarti, D.; Mo, Y.Y.; Yu, J. LncRNA HOTAIR Enhances the Androgen-Receptor-Mediated Transcriptional Program and Drives Castration-Resistant Prostate Cancer. Cell Rep. 2015, 13, 209-221. [CrossRef] [PubMed]

159. Braicu, C.; Ladomery, M.R.; Chedea, V.S.; Irimie, A.; Berindan-Neagoe, I. The relationship between the structure and biological actions of green tea catechins. Food Chem. 2013, 141, 3282-3289. [CrossRef]

160. Bernatoniene, J.; Kopustinskiene, D.M. The Role of Catechins in Cellular Responses to Oxidative Stress. Molecules 2018, 23, 965. [CrossRef]

161. Gan, R.Y.; Li, H.B.; Sui, Z.Q.; Corke, H. Absorption, metabolism, anti-cancer effect and molecular targets of epigallocatechin gallate (EGCG): An updated review. Crit. Rev. Food Sci. Nutr. 2018, 23, 965. [CrossRef]

162. Chan, M.M.; Chen, R.; Fong, D. Targeting cancer stem cells with dietary phytochemical-Repositioned drug combinations. Cancer Lett. 2018, 58, 924-941. [CrossRef]

163. Jin, G.; Yang, Y.; Liu, K.; Zhao, J.; Chen, X.; Liu, H.; Bai, R.; Li, X.; Jiang, Y.; Zhang, X.; et al. Combination curcumin and (-)-epigallocatechin-3-gallate inhibits colorectal carcinoma microenvironment-induced angiogenesis by JAK/STAT3/IL-8 pathway. Oncogenesis 2017, 433, 53-64. [CrossRef]

164. Schramm, L. Going Green: The Role of the Green Tea Component EGCG in Chemoprevention. J. Carcinog. Mutagen. 2013, 6, e384. [CrossRef]

165. Fang, M.Z.; Wang, Y.; Ai, N.; Hou, Z.; Sun, Y.; Lu, H.; Welsh, W.; Yang, C.S. Tea Polyphenol (-)-Epigallocatechin-3-Gallate Inhibits DNA Methyltransferase and Reactivates Methylation-Silenced Genes in Cancer Cell Lines. Cancer Res. 2003, 63, 7563-7570.

166. Oya, Y.; Mondal, A.; Rawangkan, A.; Umsumarng, S.; Iida, K.; Watanabe, T.; Kanno, M.; Suzuki, K.; Li, Z.; Kagechika, H.; et al. Down-regulation of histone deacetylase 4, -5 and -6 as a mechanism of synergistic enhancement of apoptosis in human lung cancer cells treated with the combination of a synthetic retinoid, Am80 and green tea catechin. J. Nutr. Biochem. 2017, 42, 7-16. [CrossRef]

167. Zhang, Y.; Wang, X.; Han, L.; Zhou, Y.; Sun, S. Green tea polyphenol EGCG reverse cisplatin resistance of A549/DDP cell line through candidate genes demethylation. Biomed. Pharmacother. 2015, 69, 285-290. [CrossRef]

168. Jin, H.; Chen, J.X.; Wang, H.; Lu, G.; Liu, A.; Li, G.; Tu, S.; Lin, Y.; Yang, C.S. NNK-induced DNA methyltransferase 1 in lung tumorigenesis in A/J mice and inhibitory effects of (-)-epigallocatechin-3-gallate. Nutr. Cancer 2015, 67, 167-176. [CrossRef]

169. Bosutti, A.; Zanconati, F.; Grassi, G.; Dapas, B.; Passamonti, S.; Scaggiante, B. Epigenetic and miRNAs Dysregulation in Prostate Cancer: The role of Nutraceuticals. Anticancer Agents Med. Chem. 2016, 16, 1385-1402. [CrossRef]

170. Fu, M.; Rao, M.; Wang, C.; Sakamaki, T.; Wang, J.; Di Vizio, D.; Zhang, X.; Albanese, C.; Balk, S.; Chang, C.; et al. Acetylation of Androgen Receptor Enhances Coactivator Binding and Promotes Prostate Cancer Cell Growth. Mol. Cell. Biol. 2003, 23, 8563-8575. [CrossRef] 
171. Lee, Y.H.; Kwak, J.; Choi, H.K.; Choi, K.C.; Kim, S.; Lee, J.; Jun, W.; Park, H.J.; Yoon, H.G. EGCG suppresses prostate cancer cell growth modulating acetylation of androgen receptor by anti-histone acetyltransferase activity. Int. J. Mol. Med. 2012, 30, 69-74.

172. Siddiqui, I.A.; Asim, M.; Hafeez, B.B.; Adhami, V.M.; Tarapore, R.S.; Mukhtar, H. Green tea polyphenol EGCG blunts androgen receptor function in prostate cancer. FASEB J. 2011, 25, 1198-1207. [CrossRef]

173. Thakur, V.S.; Gupta, K.; Gupta, S. Green tea polyphenols causes cell cycle arrest and apoptosis in prostate cancer cells by suppressing class I histone deacetylases. Carcinogenesis 2012, 33, 377-384. [CrossRef]

174. Pandey, M.; Shukla, S.; Gupta, S. Promoter demethylation and chromatin remodeling by green tea polyphenols leads to re-expression of GSTP1 in human prostate cancer cells. Int. J. Cancer 2010, 126, 2520-2533. [CrossRef]

175. Shinojima, T.; Yu, Q.; Huang, S.K.; Li, M.; Mizuno, R.; Liu, E.T.; Hoon, D.S.B.; Lessard, L. Heterogeneous epigenetic regulation of TIMP3 in prostate cancer. Epigenetics 2012, 7, 1279-1289. [CrossRef]

176. Pulukuri, S.M.; Patibandla, S.; Patel, J.; Estes, N.; Rao, J.S. Epigenetic inactivation of the tissue inhibitor of metalloproteinase-2 (TIMP-2) gene in human prostate tumors. Oncogene 2007, 26, 5229-5237. [CrossRef]

177. Lu, H.; Cao, X.; Zhang, H.; Sun, G.; Fan, G.; Chen, L.; Wang, S. Imbalance between MMP-2, 9 and TIMP-1 promote the invasion and metastasis of renal cell carcinoma via SKP2 signaling pathways. Tumor Biol. 2014, 35, 9807-9813. [CrossRef]

178. Deb, G.; Shankar, E.; Thakur, V.S.; Ponsky, L.E.; Bodner, D.R.; Fu, P.; Gupta, S. Green tea-induced epigenetic reactivation of tissue inhibitor of matrix metalloproteinase-3 suppresses prostate cancer progression through histone-modifying enzymes. Mol. Carcinog. 2019, 58, 1194-1207. [CrossRef]

179. Hafeez, B.B.; Siddiqui, I.A.; Asim, M.; Malik, A.; Afaq, F.; Adhami, V.M.; Saleem, M.; Din, M.; Mukhtar, H. A dietary anthocyanidin delphinidin induces apoptosis of human prostate cancer PC3 cells in vitro and in vivo: Involvement of nuclear factor-kB signaling. Cancer Res. 2008, 68, 8564-8572. [CrossRef]

180. Syed, D.N.; Suh, Y.; Afaq, F.; Mukhtar, H. Dietary agents for chemoprevention of prostate cancer. Cancer Lett. 2008, 265, 167-176. [CrossRef]

181. Jeong, M.H.; Ko, H.; Jeon, H.; Sung, G.J.; Park, S.Y.; Jun, W.J.; Lee, Y.H.; Lee, J.; Lee, S.W.; Yoon, H.G.; et al. Delphinidin induces apoptosis via cleaved HDAC3-mediated p53 acetylation and oligomerization in prostate cancer cells. Oncotarget 2016, 7, 56767-56780. [CrossRef]

Sample Availability: Samples of the compounds are available from the authors.

(C) 2020 by the authors. Licensee MDPI, Basel, Switzerland. This article is an open access article distributed under the terms and conditions of the Creative Commons Attribution (CC BY) license (http://creativecommons.org/licenses/by/4.0/). 